Cornell Law Library

Scholarship@Cornell Law: A Digital Repository

Cornell Law Faculty Publications

Faculty Scholarship

$10-1-1998$

\title{
Aggravation and Mitigation in Capital Cases: What Do Jurors Think?
}

Stephen P. Garvey

Cornell LawSchool, spg3@cornell.edu

Follow this and additional works at: http://scholarship.law.cornell.edu/facpub

Part of the Criminal Law Commons, and the Criminal Procedure Commons

\section{Recommended Citation}

Garvey, Stephen P., "Aggravation and Mitigation in Capital Cases: What Do Jurors Think?" (1998). Cornell Law Faculty Publications. Paper 287.

http://scholarship.law.cornell.edu/facpub/287

This Article is brought to you for free and open access by the Faculty Scholarship at Scholarship@Cornell Law: A Digital Repository. It has been accepted for inclusion in Cornell Law Faculty Publications by an authorized administrator of Scholarship@Cornell Law: A Digital Repository. For more information, please contact jmp8@cornell.edu. 


\title{
AGGRAVATION AND MITIGATION IN CAPITAL CASES: WHAT DO JURORS THINK?
}

\author{
Stephen P. Garvey*
}

The Capital Juror Project in South Carolina interviewed jurors who sat in forty-one capital murder cases. The Project asked jurors a range of questions relating to crime, the defendant, the victim, the victim's family, the jurors' deliberations, the conduct of counsel, and background characteristics of the jurors. In this essay, Professor Stephen P. Garvey presents and examines data from the Project relating to the importance jurors attach to various aggravating and mitigating factors. The results suggest that jurors have a discernible moral compass. According to the data, jurors found especially brutal killings, killings with child victims, future dangerousness, and lack of remorse to be significant aggravating factors. Conversely, jurors pointed to residual doubt over the defendant's guilt, evidence of mental retardation, youthfulness, circumstances over which the defendant had no control and which diminished his individual responsibility, and circumstances that helped form the defendant's character as mitigating factors. The findings provide valuable information to policymakers responsible for structuring the capital sentencing process and to attorneys involved in litigating capital cases.

\section{INTRODUCTION}

Imagine you represent a defendant convicted of capital murder. Now you have to plead for his life. What will you say to the jury? What can you say? What will summon its members' mercy? What will fan their wrath?

Here I present the results of an empirical study that tries to answer these questions, or at least begins to do so. The data come from a survey that asked jurors who actually sat on a capital case how they did or would react to a variety of factors in making their sentencing decision. What factors made or would have made them more or less likely to impose a death sentence? In other words, what factors in jurors' minds are aggravating and what are mitigating?

I find that jurors sitting on capital cases have a discernible moral compass, which they claim functions independently of the wishes of the victim's family or the community. On the side of aggravation, they say

* Associate Professor, Cornell Law School. B.A., Colgate University, 1987; M. Phil., Oxford University, 1989; J.D., Yale University, 1992. E-mail: <garvey@law.mail. cornell.edu>. Primary funding for the collection of data in South Carolina was provided by National Science Foundation Grant SES 90-13252. Supplementary funding was provided by the Cornell Law School and the former South Carolina Death Penalty Resource Center. Any opinions, findings, and conclusions or recommendations expressed are those of the author and do not necessarily reflect the views of the National Science Foundation. I would like to thank John Blume, Theodore Eisenberg, Sheri Johnson, Martin Wells, Russell Osgood, and Gary Simson for helpful comments. 
that all victims are of equal worth, although they grant children special consideration. They shudder at sadistic violence, and they show little mercy to defendants who show no remorse. Moreover, they are deeply concerned that such a defendant will cause more harm to someone else unless he's executed. They would rather have the defendant's blood on their hands than that of another victim.

On the side of mitigation, jurors tend to focus most on factors that diminish the defendant's individual responsibility for his actions. They attach significant mitigating potential to facts and circumstances that show diminished mental capacity, such as mental retardation or extreme emotional or mental disturbance at the time of the offense, but they have little patience for defendants who attribute their wrongdoing to drugs or alcohol. They express some concern for defendants who have suffered extreme poverty as children, more for defendants who have been seriously abused as children, and still more for defendants who tried but could not get help for their problems. Nonetheless, the mitigating effect they give these factors remains limited.

Part I describes the data used in the study. Part II describes the basics of the law of aggravation and mitigation. The heart of this Essay is Part III, which presents the results of my analysis. It tells us what jurors in capital cases say is important to them about aggravation and mitigation. However, it does not necessarily tell us what is in fact important to them. The factors that jurors say are important to their decision and the factors that actually explain their decision may not be one and the same, though we can reasonably expect at least some overlap. At any rate, the findings presented here represent the beliefs jurors are prepared to express openly.

\section{The Capital Jury Project in South Carolina}

The data analyzed here were gathered as part of the Capital Jury Project (the Project), a National Science Foundation-funded multistate research effort. ${ }^{1}$ The Project, which has been compared to the Chicago Jury Project of Harry Kalven, Jr., and Hans Zeisel, ${ }^{2}$ is intended to help us better understand how capital jurors think. In the past, researchers trying to draw inferences about how capital jurors arrive at their sentencing decision have usually been forced to rely on jury simulations, ${ }^{3}$ surveys of

1. The most complete discussion of the Capital Jury Project can be found in William J. Bowers, The Capital Jury Project: Rationale, Design, and Preview of Early Findings, 70 Ind. L.J. 1043, 1077-85 (1995).

2. See Valerie P. Hans, How Juries Decide Death: The Contributions of the Capital Jury Project, 70 Ind. L.J. 1233, 1233 (1995). Kalven and Zeisel reported their findings in Harry Kalven, Jr. \& Hans Zeisel, The American Jury (1966).

3. See, e.g., Craig Haney \& Mona Lynch, Comprehending Life and Death Matters: A Preliminary Study of California's Capital Penalty Instructions, 18 Law \& Hum. Behav. 411, 420 (1994) (juror simulation study of California instructions on college-educated students finding "widespread inability to comprehend the central terms of capital penalty phase 
the general population, anecdotes drawn from individual cases, and material in the written record. ${ }^{4}$ They simply haven't had access to data systematically gathered from jurors who actually sat on capital cases-until now. ${ }^{5}$

The data presented here come from the Project's efforts in South Carolina. Of course, the weight that South Carolina jurors attach to various aggravating and mitigating circumstances may differ from that attached by jurors in other states, but the available data suggest otherwise. On the contrary, South Carolina jurors appear to think much like jurors from several other states taken in the aggregate. ${ }^{6}$

Jurors who sat in forty-one South Carolina capital murder cases were randomly sampled. The goal was to interview four jurors per case. The sample includes twenty-two cases resulting in a death sentence ("death" cases) and nineteen cases resulting in a sentence of life imprisonment ("life" cases). ${ }^{7}$ This sample represents all South Carolina capital trials

decision making"); see also Craig Haney \& Mona Lynch, Clarifying Life and Death Matters: An Analysis of Instructional Comprehension and Penalty Phase Closing Arguments, 21 Law \& Hum. Behav. 575, 582-83, 589-91 (1997) (later simulation study finding that juror comprehension of revised California instructions remained poor and that attorney closing arguments did little to improve comprehension).

4. For an overview of empirical research on the penalty phase prior to 1992, see Mark Costanzo \& Sally Costanzo, Jury Decision Making in the Capital Penalty Phase: Legal Assumptions, Empirical Findings, and Research Agenda, 16 Law \& Hum. Behav. 185, 188-89 (1992).

5. For an earlier, less comprehensive effort to identify what actual jurors think about aggravation and mitigation, see William S. Geimer \& Jonathan Amsterdam, Why Jurors Vote Life or Death: Operative Factors in Ten Florida Death Penalty Cases, 15 Am. J. Crim. L. 1 (1987-1988) (reporting results from study of ten Florida cases involving fifty-four jurors). For the effect of various mitigating factors on support for the death penalty based on general public opinion polls, see Samuel R. Gross, Update: American Public Opinion on the Death Penalty-It's Getting Personal, 83 Cornell L. Rev. (forthcoming September 1998) (manuscript at 33-35 \& 53 tbl.6, on file with the Columbia Law Review).

6. The reactions of South Carolina capital jurors and the reactions of capital jurors from Alabama, California, Florida, Georgia, Indiana, Kentucky, Louisiana, Missouri, North Carolina, Pennsylvania, Texas, and Virginia, as well as South Carolina, are compared in the Appendix. See infra Table 10. Data regarding the reactions of jurors from these states is taken from Ellen Blau \& Marla Sandys, The Decision Makers: What Moves Jurors? (Mar. 24, 1998) (unpublished manuscript, on file with the Columbia Law Review).

7. At the time of the interviews, jurors were simply instructed to give the phrases "life imprisonment" and "death sentence" their "ordinary and plain meaning." See State v. Norris, 328 S.E.2d 339, 344 (S.C. 1985); State v. Plath, 313 S.E.2d 619, 627 (S.C. 1984). Nonetheless, most jurors didn't believe that "life imprisonment" really meant the defendant would spend the rest of his natural life in prison. Rather, they thought "life imprisonment" really meant something like fifteen to twenty-five years in prison. See Theodore Eisenberg \& Martin T. Wells, Deadly Confusion: Juror Instructions in Capital Cases, 79 Cornell L. Rev. 1, 6-7 tbl.2 (1993).

Nevertheless, South Carolina capital jurors must now be told that a defendant will be ineligible for parole: if sentenced to life imprisonment, though only if the "State puts [his] future dangerousness at issue and state law prohibits [his] release on parole ...." State v. Southerland, 447 S.E.2d 862, 868 (S.C. 1994); accord Simmons v. South Carolina, 512 U.S. 154, 156 (1994) (hclding that "where the defendant's future dangerousness is at issue, and 
through the summer of 1993 that resulted in a death sentence, and all that resulted in a life sentence which could be identified, following the enactment of the South Carolina Omnibus Criminal Justice Improvements Act of 1986.8 The 1986 law made fundamental changes in the standards of parole for capital cases and provided a natural point at which to begin collecting data. A total of 153 live interviews $(n=153)$ were completed by interviewers trained to work with the survey.

Jurors were interviewed using a fifty-one page survey instrument designed and tested by the Project and covering all aspects of the guilt and sentencing phases of the trial. It included a range of questions about the crime, the defendant, the victim, the victim's family, the jurors' deliberations, and the conduct of the case by defense counsel, the prosecutor, and the judge. The survey also asked about the jurors' background characteristics, ${ }^{9}$ as well as their general views on the death penalty and the criminal justice system. ${ }^{10}$ The same survey instrument was used in all states participating in the Project, including South Carolina.

The Project's interview methodology offers a rare opportunity to probe the beliefs and decisionmaking processes of capital jurors. Of course, this methodology also has some drawbacks. For example, jurors may not be very good at evaluating what factors influence their own thinking, or they may just give answers they think the interviewer wants to hear. ${ }^{11}$ Moreover, interviews were conducted after jurors had served, not before. Consequently, due to hindsight bias, one can't tell for certain whether their post-trial responses represent what they believed at the time of trial, or whether they instead represent rationalizations made only after the fact. ${ }^{12}$ On top of all that, jurors' memories may simply have

state law prohibits the defendant's release on parole, due process requires that the sentencing jury be informed that the defendant is parole ineligible").

8. The Omnibus Criminal Justice Improvements Act of 1986, No. 462, 1986 S.C. Acts 2955, 2983 (changing parole ineligibility for defendants convicted of capital murder with an aggravating circumstance, but not sentenced to death, from ineligibility for 20 years to ineligibility for 30 years). A later amendment to the state's capital statute changed the parole ineligibility for defendants convicted of capital murder with an aggravating circumstance, but not sentenced to death, to ineligibility for life. See Act of June 7, 1995, No. 83, 1995 S.C. Acts 545, 557. However, throughout the intervening period defendants convicted of capital murder, but not sentenced to death, were ineligible for parole for life if they had a prior conviction for a "most serious offense," including, for example, murder, assault and battery with intent to kill, kidnaping, and armed robbery. See S.C. Code Ann. $\S 17-25-45$ (A), (C) (Law. Co-op. Supp. 1997).

9. For example, $44 \%$ of the interviewed jurors were male; $56 \%$ were female. Eightythree percent were white; $17 \%$ were black. Forty-nine percent identified themselves as Baptists or Southern Baptists, $29 \%$ as members of other Protestant denominations, and 7\% as Catholics. See South Carolina Capital Juror Project Data [hereinafter Project Data] (unpublished document, on file with the Columbia Law Review).

10. See Justice Research Center, Northeastern University, Juror Interview Instrument: National Study of Juror Decision Making in Capital Cases (unpublished document, on file with the Columbia Law Review).

11. See, e.g., Hans, supra note 2, at 1235-36.

12. See, e.g., id. at 1236. 
deteriorated between the time they served and the time they were interviewed. ${ }^{13}$

Keeping these problems in mind, the work of the Project nationwide is nonetheless beginning to yield important insights into how capital jurors think. Among other things, we have good reason to believe that jurors don't really have a very good grasp of the instructions they receive. ${ }^{14}$ For example, many jurors wrongly think they must return a death sentence if they find the defendant's crime was especially heinous, or the defendant himself is especially likely to present a risk of future danger. ${ }^{15}$

13. See, e.g., id. at 1235-36. The South Carolina segment of the Project started collecting data in the early 1990s on cases that had been tried following the enactment of the South Caroline. Omnibus Criminal Justice Improvement Act of 1986. See supra note 8 and accompanying text. Consequently, the interval between the time of the trial and the time of the interview ranged for any particular juror from a few years to a few months. This delay may raise concerns about the problem of decayed or altered recall. However, assuming that jurors' reactions to aggravating and mitigating factors did not change as a result of the trial or for any other post-trial reason, their present-day responses should be relatively good indicators of their beliefs at the time of trial. Moreover, some support for these assumptions comes from the fact that $76.3 \%$ of the jurors said "no" when asked whether their "personal feelings about the death penalty"-though not about particular aggravating or mitigating factors-had "changed as a result of serving on the case." See Project Data, supra note 9. Support also comes from the finding of public opinion survey research that attitudes toward the death penalty are relatively stable insofar as a "position on capital punishrnent is [for most Americans] an aspect of self-identification." Gross, supra note 5, at 8-9. However, decayed or altered memory is a greater problem when the question is whether or not a particular aggravating or mitigating circumstance was in fact present in the case on which the juror sat.

14. Capital jurors are not unique in this respect. Jurors generally exhibit a relatively poor understanding of instructions. See, e.g., Alan Reifman et al., Real Jurors' Understanding of the Law in Real Cases, 16 Law \& Hum. Behav. 539, 552 (1992) (finding based on study of Michigan jurors in criminal and civil cases that "real jurors sitting on real cases" typically display a "poor understanding of the law"). See generally Joel D. Lieberman \& Bruce D. Scales, What Social Science Teaches Us About the Jury Instruction Process, 3 Psychol. Pub. Pol'y \& Law 589, 596-616 (1997) (reviewing literature examining "reasons why jurors fail to follow jury instructions").

For suggestions on how to respond to capital jurors' misapprehensions about the instructions they receive, see, for example, Shari Seidman Diamond \& Judith N. Levi, Improving Decisions on Death by Revising and Testing Jury Instructions, 79 Judicature 224, 224, 230-31 (1.996) (applying "linguistic principles" to revise capital jury instructions and finding that rewritten instructions resulted in improved juror understanding); James Frank \& Brandon $\mathrm{K}$. Applegate, Assessing Juror Understanding of Capital-Sentencing Instructions, 44 Crime \& Delinq. 412, 422-23 (1998) (finding based on multiple regression analysis using juror simulation study of Ohio veniremen that both rewriting instructions according to linguistic principles and providing jurors with a written copy of the original or rewritten instructions "exerted statistically significant effects" on juror comprehension); Jordan M. Steiker, The Limits of Legal Language: Decisionmaking in Capital Cases, 94 Mich. L. Rev. 2590, 2620-23 (1996) (proposing reforms that "seek to restore the moral accountability in capital sentencing that was wrongly sacrificed in the name of goals that have not and cannot be achieved by increasing the structure of the sentencing decision").

15. See Bowers, supra note 1 , at 1091 tbl.7 (reporting that between $30-40 \%$ of jurors displayed this confusion); Eisenberg \& Wells, supra note 7, at 6 tbl.2 (reporting that about $30 \%$ of South Carolina jurors displayed this confusion). 
Nor do they realize that they can rely on mitigating evidence even if its existence has not been proven beyond a reasonable doubt, ${ }^{16}$ or to the satisfaction of every single juror. ${ }^{17}$ Moreover, as a result of these confusions, jurors tend to enter their penalty-phase deliberations thinking the "default" sentence is death. ${ }^{18}$ Consequently, the de facto risk of non-persuasion rests on the defendant, not the state. We also have reason to believe that a number of jurors make up their minds about the defendant's punishment even before they hear any evidence in the penalty phase. ${ }^{19}$ Finally, jurors who are open to being persuaded generally place

16. See Eisenberg \& Wells, supra note 7, at 11 ("About half the jurors incorrectly believe that a mitigating factor must be proven beyond a reasonable doubt."); James Luginbuhl \& Julie Howe, Discretion in Capital Sentencing Instructions: Guided or Misguided?, 70 Ind. L.J. 1161, 1167 (1995) (finding that $41 \%$ of North Carolina Capital Jury Project jurors "incorrectly thought that the standard of proof for mitigating factors was proof beyond a reasonable doubt"). But cf. Eisenberg \& Wells, supra note 7, at 11 (reporting that "the great majority of jurors [correctly] understand that proof beyond a reasonable doubt is required to establish an aggravating circumstance") (emphasis added).

17. See Eisenberg \& Wells, supra note 7, at 11 ("The great majority of jurors-in excess of sixty percent in both life and death cases-erroneously believe that jurors must agree unanimously for a mitigating circumstance to support a vote against death."); Luginbuhl \& Howe, supra note 16, at 1167 (finding that $42 \%$ of North Carolina Capital Jury Project jurors "incorrectly believed that unanimity was required" in order to rely on mitigating factors); cf. James Luginbuhl, Comprehension of Judges' Instructions in the Penalty Phase of a Capital Trial, 16 Law \& Hum. Behav. 203, 214 (1992) (concluding based on simulation study of 115 North Carolina veniremen that subjects exposed to non-pattern instructions "thought that any mitigating circumstance had to be agreed upon unanimously by the jury"). But cf. Peter Meijes Tiersma, Dictionaries and Death: Do Capital Jurors Understand Mitigation?, 1995 Utah L. Rev. 1, 25 (reporting that jurorsimulation study by Hans Zeisel found that between $70-80 \%$ of jurors understood "this point of law").

18. See Eisenberg \& Wells, supra note 7, at 12 ("[I]ndecision tends to be resolved in favor of death."); id. at 14 ("Depriving jurors of full knowledge of life-favoring legal standards may not directly cause them to vote for death, but confusion about such standards mutes the impact of burdens of proof designed to favor life."); Luginbuhl \& Howe, supra note 16, at 1177 ("[E]ven before hearing the instructions, the jury is predisposed toward a verdict of death."); see also William J. Bowers \& Benjamin D. Steiner, Death By Default: An Empirical Demonstration of False and Forced Choice in Capital Sentencing, 77 Tex. L. Rev. (forthcoming February 1999) (manuscript at 58-60, on file with the Columbia Law Review) (concluding based on interviews of 916 jurors from 11 states that misunderstandings about parole eligibility are widespread and that such misunderstandings correlate with death verdicts); cf. Tiersma, supra note 17, at 32-33 (suggesting based on Zeisel study that many jurors incorrectly believe Illinois law creates a presumption in favor of death).

19. See, e.g., Bowers, supra note 1 , at $1089-90$ tbls.5 \& 6 (reporting that $64.6 \%$ of jurors nationwide who had decided before the start of the penalty phase what the defendant's punishment should be-29.5\% for death and $20.7 \%$ for life-rwere "absolutely convinced" of their decision); William J. Bowers et al., Foreclosing Impartiality in Capital Sentencing: Jurors' Predispositions, Attitudes, and Premature Decision-Making, 83 Cornell L. Rev. (forthcoming September 1998) (manuscript at 15, on file with the Columbia Law Review) ("Virtually half of the capital jurors (48.7\%) in the eleven CJP states indicated that they thought they knew what the punishment should be during the guilt phase of the trial . . . ."); Marla Sandys, Cross-Overs-Capital Jurors Who Change Their Minds About the Punishment: A Litmus Test for Sentencing Guidelines, 70 Ind. L.J. 1183, 1220 (1995) 
more trust in the testimony of lay witnesses than they do in that of experts. ${ }^{20}$

The results presented below try to add to this accumulating body of findings.

\section{The: Legal Basics of Aggravation and Mitigation}

The constitutional law of capital sentencing is a complex body of doctrine. At bottom, however, the penalty phase of a capital trial is regulated by two basic constitutional rules: A capital defendant cannot be condemned unless he is "death-eligible," nor can he be condemned unless he has had the opportunity to present any and all evidence in mitigation, free from state interference. ${ }^{21}$

(“ $[T]$ he data reveal quite dramatically that ... the majority of jurors reach their decisions about guilt and punishment at the same time.").

20. See Scott I. Sundby, The Jury as Critic: An Empirical Look at how Capital Juries Perceive Expert and Lay Testimony, 83 Va. L. Rev. 1109, 1115 (1997) (concluding based on Project data from California that "juries [in capital trials] tend to view experts as "hired guns[,]' ... [but] find certain types of lay witnesses particularly persuasive").

21. See, e.g., T'uilaepa v. California, 512 U.S. 967, 971 (1977) (distinguishing between "eligibility phase" of capital sentencing process and "selection phase"); see also James R. Acker \& C.S. Larier, Capital Murder from Benefit of Clergy to Bifurcated Trials: Narrowing the Class of Offenses Punishable by Death, 29 Crim. L. Bull. 291, 297 (1993) (noting that "Supreme Court rulings have imposed two principal limitations on capital punishment legislation[]"). For a more in-depth treatment of constitutional capitalpunishment doctrine, see Carol S. Steiker \& Jordan M. Steiker, Sober Second Thoughts: Reflections on Two Decades of Constitutional Regulation of Capital Punishment, 109 Harv. L. Rev. 355, \$71 (1995) (“[T] he Court's death penalty doctrine is complex, arcane, and minutely detailed.").

These two rules rest in turn on two principles. First, capital sentencing must be consistent (i.e., it must result in similarly situated defendants being treated similarly). Second, it must be individualized (i.e., it must treat each defendant as a unique individual). As the: Court itself has recognized, these two principles "can be in some tension." Tuilaepa, 512 U.S. at 973; see also Margaret J. Radin, Cruel Punishment and Respect for Person:s: Super Due Process for Death, 53 S. Cal. L. Rev. 1143, 1150 (1980) ("The achievable or imaginable level of individualization varies inversely with the achievable or imaginable level of consistency.") (emphasis omitted).

For scholarly commentary bearing on this doctrinal tension, see, for example, Scott W. Howe, The Failed Case for Eighth Amendment Regulation of the Capital-Sentencing Trial, 146 U. Pa. L. Rev. 795, 860-62 (1998) (concluding that the consistency principle cannot be derived from the Eighth Amendment and that the "deserts-limitation principle," which can be derived from the Eighth Amendment, only justifies the Court "in drawing categorical lines defining relatively precisely which offenders are death-eligible"); Scott W. Howe, Resolving the Conflict in the Capital Sentencing Cases: A Desert-Oriented Theory of Regulation, 26 Ga. L. Rev. 323, 361 (1992) (arguing that "[ $t$ ] he Eighth Amendment explanation for regulating capital sentencing standards is to ensure that those who receive death sentences deserve them, not to promote equality in the distribution of death sentences"); Scott E. Sundby, The Lockett Paradox: Reconciling Guided Discretion and Unguided Mitigation in Capital Sentencing, 38 UCLA L. Rev. 1147, 1185 (1991) (noting that the choice between these two principles depends on choosing between the risk of a death sentence baised on an arbitrary factor and the risk of one imposed because mitigating evidence was excluded); see also Stephen P. Garvey, "As the Gentle Rain from 
First, the Eighth Amendment limits who can be sentenced to death, or in death-penalty jargon, who is "death-eligible." 22 No state can condemn a defendant unless he falls within the "death-eligible" class. Most importantly, this means that death can only be imposed on defendants who are guilty of murder. ${ }^{23}$ Likewise, defendants under sixteen, ${ }^{24}$ or who become insane after conviction, cannot be sentenced to death or executed. ${ }^{25}$ On the other hand, it's constitutionally permissible to condemn the mentally retarded, ${ }^{26}$ at least if they're not so retarded that the common law would regard them as "idiots." 27 Finally, even defendants who are guilty of murder cannot be condemned unless the murder was "aggravated." 28 In reality, though, this limitation is "more bark than bite." 29 A statutory aggravating circumstance is constitutionally valid so long as it "reasonably justif[ies] the imposition of a more severe sentence on the defendant compared to others found guilty of murder." ${ }^{30}$ Consequently,

Heaven": Mercy in Capital Sentencing, 81 Cornell L. Rev. 989, 1004 (1996) (suggesting that the principles of individualization and consistency "interact to structure decisionmaking within the penalty phase [to] reduce[] the risk of condemning a defendant who does not deserve death").

22. See Tuilaepa, 512 U.S. at 971-72; Lowenfield v. Phelps, 484 U.S. 231, 244-46 (1988); Barclay v. Florida, 463 U.S. 939, 954 (1983) (plurality opinion); Zant v. Stephens, 462 U.S. 862, 878 (1983).

23. Cf. Coker v. Georgia, 433 U.S. 584, 592 (1977) ("[A] sentence of death is grossly disproportionate and excessive punishment for the crime of rape and is therefore forbidden by the Eighth Amendment ...."). But see State v. Wilson, 685 So. 2d 1063, 1073 (La. 1996) (holding that "in the case of the rape of a child under the age of twelve, the death penalty is not an excessive punishment nor is it susceptible of being applied arbitrarily and capriciously"), cert. denied, 117 S. Ct. 2425 (1997). See generally James R. Acker \& C.S. Lanier, The Dimensions of Capital Murder, 29 Crim. L. Bull. 379, 379-97 (1993) (providing detailed examination of state law defining capital murder).

24. See Thompson v. Oklahoma, 487 U.S. 815, 838 (1988) ("[T]he Eighth and Fourteenth Amendments prohibit the execution of a person who was under 16 years of age at the time of his or her offense."); cf. Stanford v. Kentucky, 492 U.S. 361, 380 (1989) ("[T] he imposition of capital punishment on any person who murders at 16 or 17 years of age ... does not offend the Eighth Amendment's prohibition against cruel and unusual punishment.").

25. See Ford v. Wainwright, 477 U.S. 399, 409-10 (1986) ("[T]he Eighth Amendment prohibits a State from carrying out a sentence of death upon a prisoner who is insane.").

26. See Penry v. Lynaugh, 492 U.S. 302, 328, 340 (1989) (holding that the "Eighth Amendment [does not] preclude[ ] the execution of any mentally retarded person" with at least the "reasoning capacity of a 7-year-old").

27. See id. at 333.

28. See, e.g., Zant v. Stephens, 462 U.S. 862, 876-77 (1983).

29. Steiker \& Steiker, supra note 21, at 373; cf. Steven F. Shatz \& Nina Rivkind, The California Death Penalty Scheme: Requiem for Furman?, 72 N.Y.U. L. Rev. 1283, 1326-27 (1997) (concluding based on review of cases as reported in appellate opinions that the "overwhelming majority of convicted first degree murderers satisfy one or more of [the] thirty-two special circumstances" enumerated in California's capital sentencing statute).

30. Stephens, 462 U.S. at 877. Statutory aggravating circumstances must also "genuinely narrow the class of persons eligible for the death penalty." Id.; see also Godfrey v. Georgia, 446 U.S. 420, 428 (1980) ("[A] State[ ] . . [must] define the crimes for which death may be the sentence in a way that obviates standardless sentencing discretion.") (brackets and internal quotations omitted). But cf. Arave v. Creech, 507 U.S. 463, 470-74 
states have considerable latitude to decide what turns an otherwise "simple" murder into an "aggravated" one, thus transforming a non-capital offense into a capital one.

Second, the Eighth Amendment prevents the state from defeating or limiting a defendant's plea in mitigation. No state can condemn a defendant unless he has had the chance to present to the jury any and all evidence he wishes to present in mitigation, ${ }^{31}$ which includes anything he "proffers as a basis for a sentence less than death." 32 The state can "structure" how a capital jury processes mitigating evidence, ${ }^{33}$ but it cannot prevent the defense from getting that information before the jury altogether. So, for example, while the state can require a defendant to prove the existence of a mitigating factor by a preponderance of the evidence, ${ }^{34}$ it cannot stop him from presenting evidence to the jury that, for instance, shows his comparatively minor role in the events leading up to the murder. ${ }^{35}$

The law of South Carolina reflects these two basic requirements. As with capital trials in all other states, capital trials in South Carolina are bifurcated into a "guilt stage" and a "sentencing stage." 36 The same jury that determines the defendant's guilt also determines his punishment. ${ }^{37}$ Only defendants guilty of murder-defined as the "killing of any person with malice aforethought, either express or implied"38-can be sentenced to death. ${ }^{39}$ State law lists eleven statutory aggravating circum-

(1993) (concluding that phrase "cold-blooded, pitiless slayer" is not unconstitutionally vague).

31. See Lockert v. Ohio, 438 U.S. 586, 604 (1978) (plurality opinion); see also McKoy v. North Carolina, 494 U.S. 433, 441 (1990); Mills v. Maryland, 486 U.S. 367, 374-75 (1988); Hitchcock v. Dugger, 481 U.S. 393, 398-99 (1987). See generally Louis D. Bilionis, Moral Appropriateness, Capital Punishment, and the Lockett Doctrine, 82 J. Crim. L. \& Criminology 283, 300-13 (1991) (describing the basic features of the Lockett doctrine).

32. Lockett, 433 U.S. at 604.

33. Johnson v. Texas, 509 U.S. 350, 362 (1993).

34. See Walton v. Arizona, 497 U.S. 639, 649-51 (1990).

35. See Lockett, 438 U.S. at 608.

36. See S.C. Code Ann. § 16-3-20(B) (Law. Co-op. Supp. 1997) ("When the State seeks the death penalty, upon conviction or adjudication of guilt of a defendant of murder, the court shall conduct a separate sentencing proceeding.").

37. See id. ("The [sentencing] proceeding must be conducted by the trial judge before the trial jury as soon as practicable after the lapse of twenty-four hours unless waived by the defendant.").

38. Id. § 16-3-10.

39. See id. § 16-3-20(A). 


\section{stances, ${ }^{40}$ and ten mitigating ones. ${ }^{41}$ The jury cannot consider a statutory}

40. The following circumstances are denominated "aggravating" under South Carolina law:

(1) The murder was committed while in the commission of ... [certain specified] crimes or acts[.]

…

(2) The murder was committed by a person with a prior conviction for murder.

(3) The offender by his act of murder knowingly created a great risk of death to more than one person in a public place by means of a weapon or device which normally would be hazardous to the lives of more than one person.

(4) The offender committed the murder for himself or another for the purpose of receiving money or a thing of monetary value.

(5) The murder of a judicial officer, former judicial officer, solicitor, former solicitor, or other officer of the court during or because of the exercise of his official duty.

(6) The offender caused or directed another to commit murder or committed murder as an agent or employee of another person.

(7) The murder of a federal, state, or local law enforcement officer, peace officer or former peace officer, corrections employee or former corrections employee, or fireman or former fireman during or because of the performance of his official duties.

(8) The murder of a family member of an official listed in subitems (5) and (7) above with the intent to impede or retaliate against the official. "Family member" means a spouse, parent, brother, sister, child, or person to whom the official stands in the place of a parent or a person living in the official's household and related to him by blood or marriage.

(9) Two or more persons were murdered by the defendant by one act or pursuant to one scheme or course of conduct.

(10) The murder of a child eleven years of age or under.

(11) The murder of a witness or potential witness committed at any time during the criminal process for the purpose of impeding or deterring prosecution of any crime.

Id. $\S 16-3-20(\mathrm{C})(\mathrm{a})$.

law:

41. The following circumstances are denominated "mitigating" under South Carolina

(1) The defendant has no significant history of prior criminal conviction involving the use of violence against another person.

(2) The murder was committed while the defendant was under the influence of mental or emotional disturbance.

(3) The victim was a participant in the defendant's conduct or consented to the act.

(4) The defendant was an accomplice in the murder committed by another person and his participation was relatively minor.

(5) The defendant acted under duress or under the domination of another person.

(6) The capacity of the defendant to appreciate the criminality of his conduct or to conform his conduct to the requirements of law was substantially impaired.

(7) The age or mentality of the defendant at the time of the crime.

(8) The defendant was provoked by the victim into committing the murder.

(9) The defendant was below the age of eighteen at the time of the crime. 
aggravating circumstance unless the state has proven its existence beyond a reasonable doubt. ${ }^{42}$ No standard of proof is attached to statutory mitigating circumstances.

Nevertheless, these statutory circumstances don't tell the whole story. Prosecutors and defense lawyers, including those in South Carolina, routinely introduce evidence falling outside the applicable statutory circumstances. For the defense, the right to present nonstatutory mitigating evidence is a constitutional right. ${ }^{43}$ For the state, the right to present nonstatutory aggravating evidence is a matter of state law, since the Eighth Amendment imposes few restrictions on the prosecution's power to admit nonstatutory aggravating evidence once the state has established the existence of at least one statutory aggravating circumstance. ${ }^{44}$

What are jurors supposed to do with all this evidence? South Carolina law requires that "[b]efore a convicted capital defendant may be sentenced to death, the sentencing authority must find at least one aggravating circumstance beyond a reasonable doubt." 45 Other than that, however, the law is largely silent. It does not, for instance, tell jurors to "weigh" aggravating circumstances against mitigating circumstances, as does the law of many states. ${ }^{46}$ Typically, South Carolina jurors are simply

(10) The defendant had mental retardation at the time of the crime. "Mental retardation" means significantly subaverage general intellectual functioning existing concurrently with deficits in adaptive behavior and manifested during the developmental period.

Id. $\S 16-3-20(\mathrm{C})(\mathrm{b})$.

42. See id. § 16-3-20(A).

43. See Lockett v. Ohio, 438 U.S. 586, 604 (1978).

44. See Zant v. Stephens, 462 U.S. 862, 878 (1983); accord Barclay v. Florida, 463 U.S. 939, 954 (1983); State v. Skipper, 328 S.E.2d 58, 61 (S.C. 1985) (recognizing rule under South Carolina lavv), rev'd on other grounds sub nom Skipper v. South Carolina, 476 U.S. 1 (1986); Bruce \$. Ledewitz, The New Role of Statutory Aggravating Circumstances in American Death Penalty Law, 22 Duq. L. Rev. 317, 350-51 (1984) (explaining how Stephens "permits consideration of non-statutory aggravating circumstance [sic] as a basis for the decision to impose the death penalty"). However, the state's authority to admit nonstatutory aggravating evidence is limited by other constitutional provisions, primarily the First Amendment. See, e.g., Dawson v. Delaware, 503 U.S. 159, 160 (1992) (holding that "the First and Fourteenth Amendments prohibit the introduction in a capital sentencing proceeding of the fact that the defendant was a member of [a racist organization], where the evidence has no relevance to the issues being decided in the proceeding").

45. State v. Shaw, 255 S.E.2d 799, 802 (S.C. 1979).

46. See, e.g., James R. Acker \& Charles S. Lanier, Matters of Life or Death: The Sentencing Provisions in Capital Punishment Statutes, 31 Crim. L. Bull. 19, 33-52 (1995) (describing various state-law sentencing formulas). In the jargon of death-penalty law, South Carolina is a "threshold" state, not a "weighing" state. See, e.g., State v. Elkins, 436 S.E.2d 178, 180 (S.C. 1983) ("Under our capital sentencing scheme, a jury does not 'weigh' aggravating circumstances."). This doctrinal difference probably makes little, if any, difference to jury decisionmaking. It does, however, make a difference to appellate decisionmaking. See, e.g., Stringer v. Black, 503 U.S. 222, 231-32 (1992) (noting that "[w]ith respect to the function of a state reviewing court in determining whether [a] sentence can be upheld despite the use of an improper aggravating factor, the 
provided with the relevant list of aggravating and mitigating factors and instructed that they may impose a life sentence for "any reason or for no reason at all." ${ }^{77}$ The jury's sentencing decision, whether for life imprisonment or for death, must be unanimous; otherwise, the defendant is sentenced by operation of law to "life imprisonment," which "means [imprisonment] until death of the offender." 48 The jury's decision, though formally denominated a "recommendation" to the court, is in fact binding. ${ }^{49}$

So much for the legal framework of aggravation and mitigation, which tells us what the law thinks makes a bad crime more or less bad. What, though, do capital jurors think?

At the outset, bear in mind that capital jurors are not like other jurors. Unlike other jurors, they are "death-qualified." A potential juror whose scruples against the death penalty would "prevent or substantially impair the performance of his duties as a juror in accordance with his instructions and his oath" 50 can be challenged for cause by the state. ${ }^{51}$

difference . . is . . of critical importance"). But cf. Steiker \& Steiker, supra note 21, at 386 87 (' $[T]$ he different doctrinal approaches to 'weighing' and 'non-weighing' schemes are difficult to justify given that the sentencer's decisionmaking process is likely to be similar under either scheme."). See generally Srikanth Srinivasan, Note, Capital Sentencing Doctrine and the Weighing-Nonweighing Distinction, 47 Stan. L. Rev. 1347 (1995) (discussing implications of weighing-nonweighing distinction for Eighth Amendment capital sentencing doctrine).

47. Interview with John Blume, Director, Cornell Death Penalty Project (Nov. 21, 1997) [hereinafter Blume Interview]. Mr. Blume was the Executive Director of the South Carolina Death Penalty Resource Center from 1988 to 1996. He continues to litigate capital cases in South Carolina and is well-acquainted with capital practice in that state. It should be noted that not all South Carolina trial judges use this exact language in their charge, and the South Carolina Supreme Court will uphold alternative language provided it "convey[s] the [same] substance." State v. Green, 392 S.E.2d 157, 164 (S.C. 1990).

48. S.C. Code Ann. § 16-3-20(A) (Law. Co-op. Supp. 1997).

49. See, e.g., Shaw, 255 S.E.2d at 802 ("When the trial jury is the sentencing authority, its recommendation for punishment is binding on the court."); see also Theodore Eisenberg et al., Jury Responsibility in Capital Sentencing: An Empirical Study, 44 Buff. L. Rev. 339, 351 \& n.52 (1996) (collecting typical South Carolina jury charges that convey the binding nature of the jury's sentencing recommendation).

50. Wainwright v. Witt, 469 U.S. 412, 424 (1985) (footnote and quotations omitted).

51. See id.; see also Witherspoon v. Illinois, 391 U.S. 510, 522 (1968) ("[A] sentence of death cannot be carried out if the jury that imposed or recommended it was chosen by excluding veniremen for cause simply because they voiced general objections to the death penalty or expressed conscientious or religious scruples against its infliction.").

Prosecutors also use peremptory challenges to remove prospective jurors who express reservations about the death penalty but who cannot be challenged for cause. See Bruce Winick, Prosecutorial Peremptory Challenge Practices in Capital Cases: An Empirical Study and a Constitutional Analysis, 81 Mich. L. Rev. 1, 21 (1982) (concluding based on study of practices in Florida's Fourth Judicial Circuit between 1974 and 1978 "that the prosecution relie[s] on its peremptory challenges to systematically exclude death-scrupled individuals from capital juries").

Capital jurors are also "life-qualified," i.e., a potential juror who would impose death no matter what evidence the defense presented can be challenged for cause by the defense. See Morgan v. Illinois, 504 U.S. 719, 729 (1992) ("A juror who will automatically 
Consequently, jurors with principled reservations against the death penalty usually do not make it onto capital juries. ${ }^{52}$ More importantly, we know from prior research that compared to jurors who are not deathqualified, death-qualified jurors are more prone to convict. ${ }^{53}$ We also have reason to believe that they are more receptive to aggravating circumstances. ${ }^{54}$ Despite these troublesome consequences, the practice of death-qualification has survived constitutional challenge. ${ }^{55}$

Now to the data.

vote for the death penalty in every case will fail in good faith to consider the evidence of aggravating and mitigating circumstances as the instructions require him to do."). Defense lawyers can also use peremptory challenges to remove prospective jurors who express reservations about certain mitigating factors but who cannot be challenged for cause.

52. For example, $34.2 \%$ of the jurors reported that they were "strongly in favor" of the death penalty for convicted murderers, $40.9 \%$ that they were "somewhat in favor," $16.1 \%$ that they were "somewhat opposed," and 3.4\% that they were "strongly opposed." The remainder reported that they were "not sure" or "didn't know." See Project Data, supra note 9.

53. See, e.g., Craig Haney, On the Selection of Capital Juries: The Biasing Effects of the Death-Qualification Process, 8 Law \& Hum. Behav. 121, 128 (1984) ("Exposure to death qualification increase[s jurors'] belief in the guilt of the defendant and their estimate that he [will] be convicted."); William C. Thompson et al., Death Penalty Attitudes and Conviction Proneness: The Translation of Attitudes into Verdicts, 8 Law \& Hum. Behav. 95, 111 (1984) (finding based on experimental empirical study that deathqualified jurors are more conviction-prone because they interpret testimony in a way more favorable to the siate and because less evidence is required to convince them of guilt beyond a reasonable doubt); see also Craig Haney et al., "Modern" Death Qualification: New Data on Its Biasing Effects, 18 Law \& Hum. Behav. 619, 631 (1994) (Deathqualification "continues to produce a group of eligible jurors in capital cases-under whatever standard they are defined-that appear to be significantly different in a number of important dimensions from jurors eligible to sit on any other kind of criminal case").

54. See James Luginbuhl \& Kathi Middendorf, Death Penalty Beliefs and Jurors' Responses to Aggravating and Mitigating Circumstances in Capital Trials, 12 Law \& Hum. Behav. 263, 275 (1988) (concluding based on study of 325 North Carolina veniremen that Witherspoon-excludable jurors "were significantly less supportive of aggravating circumstances thar, the remaining, death-qualified jurors, while they did not differ with regard to overall acceptance of mitigating circumstances"); cf. Ronald C. Dillehay \& Marla R. Sandys, Life Under Wainuright v. Witt: Juror Dispositions and Death Qualification, 20 Law \& Hum. Behav. 147, 159 (1996) (finding based on survey of 148 Kentucky felony jurors that " $28.2 \%(N=42)$ of those classified as includable by the Witt standard would ... always give the death penalty for intentional murder, regardless of the evidence"); Jane Goodman-Delahunty et al., Construing Motive in Videotaped Killings: The Role of Jurors' Attitudes Toward the Death Penalty, 22 Law \& Hum. Behav. 257, 269 (1998) (finding based on mock jury' study that death-qualified jurors were more likely "to infer . . . (1) that the defendant intended to murder the victim, (2) that his specific actions indicated premeditation, (3) that the defendant's substance abuse did not mitigate his actions, and (4) that the defenclant would be a future threat to society").

55. See Lockhart v. McCree, 476 U.S. 162, 173 (1986) (rejecting a constitutional challenge to death-qualification based on the empirically-demonstrated "convictionproneness" of death-qualified juries and concluding that the "Constitution does not prohibit the States from 'death-qualifying' juries in capital cases"). 


\section{Capital Jurors' Reactions to Aggravating and Mitigating Factors}

The tables below present juror reactions to an extensive, but by no means exhaustive, list of possible aggravating and mitigating factors. The survey instrument asked jurors how they did react (if the circumstance was present in their case), ${ }^{56}$ or how they would have reacted (if it was not), to various aggravating and mitigating factors relating to events surrounding the killing itself (Table 2), to the victim (Table 3), and to the defendant (Table 4). ${ }^{57}$ Did or would this or that factor make them much or slightly more likely to vote for death? Did or would it make them much or slightly less likely to vote for death? Or, did or would it leave them just as likely to vote for death?

Note that the survey asked jurors how they would react, not how they thought the law expected or required them to act. Nonetheless, it's entirely possible that at least some jurors may have construed the question in this way, in which case the jurors' responses reflect their beliefs about the law's preferences, and not necessarily the jurors' own.

For simplicity's sake, the tables presented below show only aggregate juror responses. Jurors are not disaggregated in any way. In particular, jurors are not broken down by whether they sat on a case that resulted in a life sentence or a death sentence, or by whether they sat on a case in which the particular aggravating or mitigating circumstance in question was or was not actually present. ${ }^{58} \mathrm{I}$ don't present these breakdowns in the text because - as I read the data-they generally leave unchanged the basic patterns observed in the aggregate data. Moreover, most of the differences were statistically insignificant. Where the patterns revealed in these breakdowns differ markedly from the aggregate-data patterns, I try to point out the differences. I also supply these breakdowns in an Appendix, both for the sake of completeness and because others may see things in the data that escape me. ${ }^{59}$

Although the aggregate data and disaggregated data generally reveal the same basic patterns, one noticeable difference does emerge. If you look at jurors' reactions to aggravating and mitigating circumstances bro-

56. Jurors who indicated that a particular factor was present were also asked how important the factor was in their punishment decision on a scale ranging from "not important" to "fairly important" to "very important." I have not analyzed those responses here.

57. After accounting for missing responses, the number of respondents for any given factor ranged from 135 to 151 .

58. Nor are jurors broken down according to demographic variables, such as sex, age, socioeconomic status, or religion. However, because race generally plays such a large part in capital sentencing, I have provided a breakdown of jurors' responses according to race. See infra Table 9. Only two differences were statistically significant. First, black jurors were more likely to treat as aggravating the fact that the victim was a respected member of the community. Second, white jurors were more likely to treat as aggravating the fact that the defendant might be a danger to society in the future. See infra Table 9.

59. See infra Appendix. 
ken down by whether the jury sentenced the defendant to life or death, ${ }^{60}$ you see that jurors who sat on death cases tended to be less moved by aggravating and mitigating circumstances across the board. ${ }^{61}$ Death-case jurors were more likely than life-case jurors to report that a particular aggravating or mitigating circumstance would make them just as likely to vote for death, whereas life-case jurors were more likely than death-case jurors to report that a particular aggravating or mitigating circumstance would make them more or less likely to vote for death.

This relative lack of movement among death-case jurors suggests one of two possibilities. First, jurors in death cases may become "vested" ex post in the moral propriety of their decision. Having decided to impose death, they may come to think that their decision was unique and perhaps inevitable. Nothing, they may think, could have made a difference one way or another. If so, then we should expect to see, as we do, more "just as likely" responses from death-case jurors than from life-case jurors. Alternatively, death-case jurors may differ from life-case jurors ex ante. In other words, death-case jurors may simply think about aggravation and mitigation differently than do life-case jurors going into the penalty phase. Either explanation is possible based on the limited analysis presented here.

\section{A. Independent Agents}

Some of the factors explored jurors' reactions to the reactions of others. How, for example, did or would it affect a juror's sentencing decision if the victim's family or the community wanted the defendant sentenced to death, or the victim's family had "suffered severe loss or grief," or the community was "outraged over the crime"? The results presented in Table 1 suggest that such things have relatively little effect.

For example, $88.2 \%$ said they would be just as likely to impose death if the victim's family asked for it, and only $9.1 \%$ said they would be more likely. Similarly, community sentiment in favor of death made little difference to most jurors, with $91.6 \%$ reporting that they would be just as likely to vote for death despite the fact that most members of the community wanted the death penalty. These figures change somewhat if the jurors believed the factor was actually present. For example, among jurors who actually thought the victim's family wanted death, the percentage responding "just as likely" dropped to $75.0 \%$, while the percentage re-

60. See infra Tables 5-8.

61. The percentage of jurors in death cases who responded "just as likely" was greater than jurors in life cases for all but three of the factors. This "fixity" of opinion among death-case jurors appears less pronounced when the aggravating and mitigating factors relate to the defenclant. See infra Table 8. 
TABLE 1

Aggravating and Mitigating Factors

RELATING TO THE OPINIONS OF OtHERS

(Survey Question IV.B.1)

\begin{tabular}{|c|c|c|c|c|c|}
\hline \multicolumn{6}{|c|}{ Did or would this factor make you . . . likely to vote for death (\% responding) } \\
\hline & $\begin{array}{l}\text { much } \\
\text { more }\end{array}$ & $\begin{array}{c}\text { slightly } \\
\text { more }\end{array}$ & $\begin{array}{c}\text { just } \\
\text { as }\end{array}$ & $\begin{array}{c}\text { slightly } \\
\text { less }\end{array}$ & $\begin{array}{c}\text { much } \\
\text { less }\end{array}$ \\
\hline $\begin{array}{l}\text { victim's family suffered severe loss or grief } \\
(n=135)\end{array}$ & 9.6 & 11.1 & 77.0 & 2.2 & 0.0 \\
\hline victim's family asked for death penalty ( $\mathrm{n}=144)$ & 2.8 & 6.3 & 88.2 & 2.8 & 0.0 \\
\hline community was outraged over crime $(n=139)$ & 4.3 & 5.8 & 87.8 & 0.7 & 1.4 \\
\hline $\begin{array}{l}\text { most community members wanted death penalty } \\
(\mathrm{n}=142)\end{array}$ & 2.8 & 3.5 & 91.6 & 0.0 & 2.1 \\
\hline
\end{tabular}

sponding "more likely" increased to $16.7 \% .^{62}$ Still, all-in-all, capital sentencing jurors tended to consider themselves "independent agents."

In a separate study of the same South Carolina jurors examined here, my colleagues and I reached conclusions consistent with these findings. ${ }^{63}$ In that study we found that if you asked jurors who, as between themselves and the judge and appeals courts, was "responsible" for "whether [the] defendant lived or died," most said that the "life or death decision was mostly or strictly the jury's responsibility." 64 In fact, this is how the Constitution expects them to think, since it's "constitutionally impermissible to rest a death sentence on a determination made by a sentencer who has been led to believe that the responsibility for determining the appropriateness of the defendant's death rests elsewhere." 65

62. See infra Table 5. Similarly, among jurors who actually believed that most members of the community wanted death, $19.4 \%$ said they would be more likely to vote for death, compared to $6.3 \%$ in the aggregate data. See infra Table 5.

63. See Eisenberg et al., supra note 49 .

64 . Id. at 354 (finding that $59 \%$ of capital jurors "stated that the life or death decision was mostly or strictly the jury's responsibility"). But cf. Craig Haney, Violence and the Capital Jury: Mechanisms of Moral Disengagement and the Impulse To Condemn to Death, 49 Stan. L. Rev. 1447, 1475 (1997) (suggesting that Capital Jury Project data "confirm" Robert Weisberg's thesis that capital "jurors artificially distance themselves from choices by relying on legal formalities") (quoting Robert Weisberg, Deregulating Death, 1983 Sup. Ct. Rev. 305, 391); Joseph L. Hoffmann, Where's the Buck?-Juror Misperception of Sentencing Responsibility in Death Penalty Cases, 70 Ind. L.J. 1137, 1156 (1995) (concluding based on narrative accounts of Indiana Capital Jury Project jurors that "[d]uring the jury deliberations, most jurors found ways to overcome, or avoid confronting, their sense of personal moral responsibility for the defendant's fate"); Austin Sarat, Violence, Representation, and Responsibility in Capital Trials: The View from the Jury, 70 Ind. L.J. 1103, 1135 (1995) ("[T] he law, with its elaborate structure of rules, reviews, and appeals in capital cases, diffuses responsibility for the violence which jurors are asked to authorize.").

65. Caldwell v. Mississippi, 472 U.S. 320, 328-29 (1985); cf. Stanton D. Krauss, Representing the Community: A Look at the Selection Process in Obscenity Cases and Capital Sentencing, 64 Ind. L.J. 617, 617-18 (1989) ("[T]he law trusts that the decisions of a randomly selected group of people voting as 'free agents' can be expected to mirror the community's preferences."). 
Of course, not all jurors thought that way. A disconcertingly large minority said that responsibility for the life or death decision was partly or mostly the judges' or appeals courts'. ${ }^{66}$

Moreover, at the time of the survey, the Constitution did not allow the state to introduce so-called "victim impact" testimony. ${ }^{67}$ The constitutional bar on such evidence no longer exists. Prosecutors are now free to introduce such testimony, ${ }^{68}$ and South Carolina prosecutors make regular use of it. ${ }^{69}$ Members of the victim's family can now testify about the victim's life and how the crime affected them personally. ${ }^{70}$ Having been exposed to such testimony, jurors may come to think of themselves almost as the victim's agent, thus potentially eroding any prevailing norms of jury independence or individual juror responsibility.

\section{B. Aggravation}

The law has long tried to figure out what crimes deserve the death penalty. One early solution was to divide the domain of murder into two categories, premeditated and non-premeditated, with death being reserved for the former. ${ }^{71}$ Today's solution is different. The law now focuses less on the subjective mind of the killer and more on the objective

66. See Eisenberg et al., supra note 49 , at 353 tbl.1 (reporting that $41 \%$ of capital jurors stated that responsibility for the life or death decision was partly or mostly the courts' responsibility); see also William J. Bowers, The Capital Jury: Is It Tilted Toward Death?, 79 Judicature 220, 223 (1996) (analyzing Capital Jury Project data from several states and emphasizing that "[m]ost capital jurors disclaim primary or sole responsibility for the awesome life or death decision they must make").

The underlying concern is that jurors who for whatever reason don't believe they are personally responsible for the defendant's sentence will be more likely to impose death than jurors who do believe they are personally responsible, and indeed, according to one recent study, a "modest correlation [does] . . . exist [ ] between rejection of responsibility and sentencing to death." Eisenberg et al., supra note 49, at 377. Still, the study's authors were unable to reject the "hypothesis of no significant relationship between jurors' perceptions of responsibility and sentencing outcome." Id.

67. See South Carolina v. Gathers, 490 U.S. 805, 810 (1989) ("'[V]ictim impact statements' in capital sentencing proceedings violate[ ] [the] principle that a sentence of death must be related to the moral culpability of the defendant."); Booth v. Maryland, 482 U.S. 496, 502-03 (1987) (holding that victim impact evidence "is irrelevant to a capital sentencing decision").

68. See Payne v. Tennessee, 501 U.S. 808, 830 n.2 (1991) (overruling holdings of Booth and Gathers that "evidence and argument relating to the victim and the impact of the victim's death on the victim's family are inadmissable at a capital sentencing hearing").

69. See Blume: Interview, supra note 47.

70. Victim impact evidence typically includes evidence about the life and character of the victim, as well as evidence relating to the impact of the victim's death on his or her family members. Both kinds of evidence are admissible under Payne. See Payne, 501 U.S. at 830 n.2. However, Booth and Gathers may continue to ban "a victim's family members' characterizations and opinions about the crime, the defendant, and the appropriate sentence ...." Id.; see also id. at 835 n.1 (Souter, J., concurring) (citing Booth, 482 U.S. at 508-09).

71. See Daniel Givelber, The New Law of Murder, 69 Ind. L.J. 375, 380 (1994) ("The traditional law of murder employed two tests to distinguish between those who could be 
facts of his crime, i.e., on "aggravating factors."72 How do jurors react to these factors?

\section{TABLE 2}

Aggravating and Mrtigating Factors

RELATING TO THE KIILING

(Survey Question IV.B.1)

\begin{tabular}{|c|c|c|c|c|c|}
\hline Did or would this factor make you . . . I & $y$ to & e for $c$ & th & respor & ing) \\
\hline & $\begin{array}{l}\text { much } \\
\text { more }\end{array}$ & $\begin{array}{l}\text { slightly } \\
\text { more }\end{array}$ & $\begin{array}{l}\text { just } \\
\text { as }\end{array}$ & $\begin{array}{l}\text { slightly } \\
\text { less }\end{array}$ & $\begin{array}{c}\text { much } \\
\text { less }\end{array}$ \\
\hline killing was not premeditated $(n=143)$ & 16.8 & 16.1 & 37.1 & 17.5 & 12.6 \\
\hline killing was especially bloody or gory & & & & & \\
\hline$(\mathrm{n}=137)$ & 38.7 & 20.4 & 38.0 & 1.5 & 1.5 \\
\hline $\begin{array}{l}\text { killing was brutal, involving torture or } \\
\text { physical abuse }(n=140)\end{array}$ & 62.1 & 13.6 & 22.9 & 0.0 & 1.4 \\
\hline $\begin{array}{l}\text { killing was committed under influence of } \\
\text { alcohol }(n=147)\end{array}$ & 8.8 & 4.8 & 68.0 & 12.2 & 6.1 \\
\hline $\begin{array}{l}\text { killing was committed under influence of } \\
\text { drugs }(n=146)\end{array}$ & 11.0 & 6.9 & 63.7 & 12.3 & 6.2 \\
\hline $\begin{array}{l}\text { killing was committed under influence of } \\
\text { extreme mental or emotional } \\
\text { disturbance }(n=143)\end{array}$ & 3.5 & 4.9 & 37.1 & 30.1 & 24.5 \\
\hline $\begin{array}{l}\text { defendant made victim suffer before death } \\
(n=142) \\
\text { defendant maimed or mutilated victim }\end{array}$ & 50.0 & 22.5 & 26.1 & 1.4 & 0.0 \\
\hline after death $(n=144)$ & 57.6 & 14.6 & 26.4 & 0.7 & 0.7 \\
\hline
\end{tabular}

1. Especially brutal murders are highly aggravating. - Looking at Table 2, a large majority of jurors would be at least slightly more likely to impose death if the crime involved torture or physical abuse, or if the defendant made the victim suffer before death. A smaller but still significant majority of jurors would also be at least slightly more likely to impose death if the crime was especially bloody or gory. ${ }^{73}$ Moreover, how the defendant treated the victim's body after death is almost as important as how he treated the victim before death, with over $70.0 \%$ of jurors indicating that post-mortem maiming or mutilation of the victim's body did or would make them more likely to impose death. ${ }^{74}$

executed (first-degree murderers) and those who could not: the existence of premeditation and deliberation, and the doctrine of felony murder.") (footnote omitted).

72. See id. at 377.

73. Most death penalty states make the nature of the killing a statutory aggravating circumstance. See, e.g., James R. Acker \& C.S. Lanier, "Parsing This Lexicon of Death": Aggravating Factors in Capital Sentencing Statutes, 30 Crim. L. Bull. 107, 125 (1994) ("Statutes in seventeen of the [then] thirty-seven death penalty jurisdictions use some version of the ['heinous, atrocious or cruel'] sentencing circumstance, and related provisions appear in twelve other capital sentencing statutes.") (footnotes omitted).

74. These basic findings tended to hold true whether or not the factor was actually present in the case on which the juror sat, although some marked variation does exist with respect to certain factors. See infra Table 6 . 
Indeed, the overall impact of these aggravating factors is even greater than Table 2 suggests, because most jurors actually thought these factors were present in the cases on which they sat. For example, $61.9 \%$ found that the murder involved torture or physical abuse, $62.5 \%$ that it was bloody or gory, and $58.8 \%$ that the defendant made the victim suffer before death. ${ }^{75}$

TABLE 3

Aggravating and Mitigating Factors

RELATING TO THE VICTIM

(Survey Question IV.B.1)

\begin{tabular}{lrrrrr}
\hline \multicolumn{6}{c}{ Did or would this factor make you ... likely to vote for death (\% responding) } \\
\hline & $\begin{array}{r}\text { much } \\
\text { more }\end{array}$ & $\begin{array}{r}\text { slightly } \\
\text { more }\end{array}$ & $\begin{array}{c}\text { just } \\
\text { as }\end{array}$ & $\begin{array}{c}\text { slightly } \\
\text { less }\end{array}$ & $\begin{array}{c}\text { much } \\
\text { less }\end{array}$ \\
\hline victim was female $(\mathrm{n}=142)$ & 2.1 & 7.8 & 88.7 & 0.0 & 1.4 \\
victim was child (n=151) & 45.7 & 16.6 & 37.1 & 0.0 & 0.7 \\
victim was respected member in & & & & & \\
$\quad$ community ( $\mathrm{n}=1$ 39) & 5.0 & 6.5 & 84.9 & 2.9 & 0.7 \\
victim was stranger in community (n=148) & 4.1 & 1.4 & 91.2 & 2.0 & 1.4 \\
victim was known troublemaker $(\mathrm{n}=149)$ & 2.0 & 7.4 & 73.2 & 11.4 & 6.0 \\
victim had criminal record ( $\mathrm{n}=151)$ & 2.0 & 5.3 & 82.1 & 5.3 & 5.3 \\
victim was an alcoholic $(\mathrm{n}=151)$ & 0.7 & 2.7 & 90.1 & 5.3 & 1.3 \\
victim was a drug addict $(\mathrm{n}=151)$ & 0.7 & 2.0 & 90.1 & 6.0 & 1.3 \\
victim had a loving family $(\mathrm{n}=138)$ & 4.4 & 6.5 & 86.2 & 2.2 & 0.7
\end{tabular}

2. Murders involving child victims are highly aggravating, but otherwise jurors claim that the victim's status and standing make little difference. - Looking at Table 3, the most striking result involves victims who are children. A sizeable majority of jurors would be more likely to impose death if the victim was a child. In contrast, other facts about the victim generally made little difference, at least if the jurors' responses are taken at face value. For example, most jurors would be just as likely to impose death if the victim was female as if the victim was male. Similarly, whether the victim was a stranger in the community or a respected member of it, whether the victim was a troublemaker or had a criminal record, and whether the victim was an alcoholic or drug addict made little difference. Nor did it make much difference whether the victim had a loving family. ${ }^{76}$

Although these findings suggest that jurors value the lives of all victims equally, extreme caution is in order. First, what jurors say and what

75. See infra Table 6 . Only $16.5 \%$ found that the defendant maimed or mutilated the victim after death. See infra Table 6.

76. The status of the defendant didn't seem to make much difference either. For example, $93.7 \%$ of the jurors said that they would be just as likely to impose death if the defendant was a "stranger in the community." See infra Table 4. Nonetheless, this result should be interpreted with extreme caution. It may well only reflect how jurors believe they should act, not how they actually do. 
they do are not necessarily the same thing. Actions speak louder than words, and despite what they say, evidence exists that jurors in fact tend more readily to condemn defendants who kill "high-value" victims than they do those who kill "low-value" ones. ${ }^{77}$ Jurors who claim to value all victims equally but whose sentencing decision tends to reflect their sense of the victim's relative worth may or may not be self-consciously aware of the inconsistency. Moreover, consistent with this evidence, $17.4 \%$ of jurors indicate that they would treat as mitigating the fact that the victim "was a known troublemaker," and $10.6 \%$ would treat as mitigating the fact that the victim "had a criminal record."

Second, it makes a difference whether or not a particular victim characteristic was actually present. For example, when the victim was in fact a female, the percentage of jurors who found that fact aggravating jumped from $4.2 \%$ to $21.3 \% .^{78}$ Similarly, when jurors believed the victim was in fact a "respected member of the community," the percentage of jurors who treated that fact as aggravating jumped from $1.7 \%$ to $20.1 \%{ }^{79}$

Third, as mentioned earlier, ${ }^{80}$ at the time of the survey jurors were not allowed to hear "victim impact" evidence. Federal constitutional law barred such evidence. ${ }^{81}$ That bar no longer exists, ${ }^{82}$ and prosecutors in

77. For example, in their seminal study of capital sentencing in Georgia, David Baldus and his colleagues found that "low-status victim" was "related to a statistically significant degree with the sentencing outcome." David Baldus et al., Equal Justice and the Death Penalty: A Legal and Empirical Analysis 157 (1990) [hereinafter Baldus et al., Equal Justice]. They also found that "in contrast to juries, prosecutors placed more weight on the ... defendant-victim relationship, but placed less weight on the sex and socioeconomic status of the victim." Id. at 169; see also David Baldus et al., Race Discrimination and the Death Penalty in the Post Furman Era: An Empirical and Legal Overview, with Preliminary Findings from Philadelphia, 83 Cornell L. Rev. (forthcoming September 1998) (manuscript at 70-71, on file with the Columbia Law Review) [hereinafter Baldus et al., Preliminary Findings] (finding based on study of capital sentencing in Philadelphia that "defendants with . . . victims of more than minimal [socio-economic status] face, on average, a distinctly higher risk of receiving a death sentence than similarly situated ... defendants with victims of low [socio-economic status]"); James C. Beck \& Robert Shumsky, A Comparison of Retained and Appointed Counsel in Cases of Capital Murder, 21 Law \& Hum. Behav. 525, 536 (1997) (analyzing Baldus data and similarly concluding that "[d] efendants were more often sentenced to death ... when victim's social status was higher than lower, and when the defendant and victim were strangers rather than acquaintances").

78. See infra Table 7.

79. See infra Table 7.

80. See supra notes $67-70$ and accompanying text.

81. See South Carolina v. Gathers, 490 U.S. 805, 810 (1989); Booth v. Maryland, 482 U.S. 496, 502-03 (1987).

82. See Payne v. Tennessee, 501 U.S. 808, 830 (1991) (overruling Booth and Gathers). 
South Carolina now routinely present victim impact evidence. ${ }^{83}$ As a result, the status of the victim may become increasingly salient. ${ }^{84}$

Fourth, we: know from other studies that the race of the victim plays a large role in determining who gets death. For example, the well-known "Baldus study" of Georgia's capital sentencing system found that the race of the victim exercised a strong influence on prosecutorial charging decisions. ${ }^{85}$ A 1983 study of prosecutorial charging in South Carolina reached a similar conclusion. 86 Prosecutors tended to value the lives of white victims more than they did the lives of black victims insofar as they tended to charge capital murder more often in white-victim murders than they did in black-victim murders, all else being equal. According to Professor Baldus and his colleagues, "[t]he exercise of prosecutorial discretion is the principal source of the race-of-victim disparities observed in the system." 87 Although the results in which Baldus and his colleagues had the most confidence did not reveal any statistically significant race-ofvictim effect attributable to jury decisionmaking, their results overall were "mixed."88 Moreover, more recent research Baldus has conducted in Pennsylvania does find a distinct and statistically significant race-of-victim effect attributable to the decisionmaking of jurors. ${ }^{89}$

83. See Blume: Interview, supra note 47 . South Carolina law allows the state to admit evidence of the victim's good character, see, e.g., State v. Johnson, 410 S.E.2d 547, 555 (S.C. 1991) (adopting Payne), but it bars the defense from admitting evidence of the victim's bad character. See, e.g., State v. Southerland, 447 S.E.2d 862, 867 (S.C. 1994); cf. State v. Gaskins, 3:6 S.E.2d 132, 145 (S.C. 1985) (holding victim's confession to murder properly excluded).

84. See, e.g., Susan Bandes, Empathy, Narrative, and Victim Impact Statements, 63 U. Chi. L. Rev. 361, 406 (1996) ("Victim impact statements permit, and indeed encourage, invidious distinctions about the personal worth of victims.").

85. See, e.g., Baldus et al., Equal Justice, supra note 77, at 403.

86. See Raymond Paternoster, Race of Victim and Location of Crime: The Decision To Seek the Death Penalty in South Carolina, 74 J. Crim. L. \& Criminology 754, 784 (1983) (concluding based on empirical analysis that the "prosecutor's decision to seek the death penalty [in South (Carolina] is significantly related to the race of the victim").

87. Baldus et al., Equal Justice, supra note 77, at 403.

88. Id. With respect to jury decisionmaking, Baldus and his colleagues concluded:

The results of our analyses of jury penalty-trial decisions were mixed. Some estimates from the PRS [Procedural Reform Study] showed a statistically significant race-of-victim effect, but the PRS results in which we have the most confidence, although fairly large, do not attain statistical significance at the .05 level, nor do the jury race-of-victim results from the CSS [Charging and Sentencing Study].

Id. (footnote omitted).

89. See Baldus et al., Preliminary Findings, supra note 77, at 72 ("The Philadelphia results are distinguishable from those estimated in earlier studies in [the] South in that the principal source of the race disparities in Philadelphia is jury rather than prosecutorial decision making."); see also David C. Baldus et al., Reflections on the "Inevitability" of Racial Discrimination in Capital Sentencing and the "Impossibility" of Its Prevention, Detection, and Correction, 51 Wash. \& Lee L. Rev. 359, 407-10 \& 408 tbl.3 (1994) (reporting substantial and statistically significant race-of-defendant disparity in 123 deatheligible New Jersey cases between 1982 and 1991 attributable to jury decisionmaking "after 
TABLE 4

Aggravating and Mitigating Factors

RELATING TO THE DeFENDANT

(Survey Question IV.B.1)

\begin{tabular}{|c|c|c|c|c|c|}
\hline Did or would this factor make you & sely to & ote fo & eath & \%o res & ng) \\
\hline & $\begin{array}{l}\text { much } \\
\text { more }\end{array}$ & $\begin{array}{l}\text { slightly } \\
\text { more }\end{array}$ & $\begin{array}{l}\text { just } \\
\text { as }\end{array}$ & $\begin{array}{l}\text { slightly } \\
\text { less }\end{array}$ & $\begin{array}{c}\text { much } \\
\text { less }\end{array}$ \\
\hline $\begin{array}{l}\text { defendant had a history of violent crime } \\
(n=144)\end{array}$ & 28.5 & 24.3 & 46.5 & 0.7 & 0.0 \\
\hline defendant would be a well-behaved & $0 \Omega$ & & & & 9 \\
\hline $\begin{array}{l}\text { 1nmate }(n=141) \\
\text { defendant might be a danger to society }\end{array}$ & 0.0 & 0.7 & 73.1 & 17.0 & 9.2 \\
\hline in the future $(n=140)$ & 37.9 & 20.0 & 40.7 & 1.4 & 0.0 \\
\hline $\begin{array}{l}\text { defendant had no previous criminal } \\
\text { record }(n=135)\end{array}$ & 4.4 & 5.2 & 70.4 & 13.3 & 6.7 \\
\hline defendant was mentally retarded $(n=149)$ & 0.7 & 2.0 & 23.5 & 29.5 & 44.3 \\
\hline $\begin{array}{l}\text { defendant was under } 18 \text { at the time of } \\
\text { the crime }(n=147)\end{array}$ & 0.7 & 2.7 & 55.1 & 27.9 & 13.6 \\
\hline defendant was an alcoholic $(n=146)$ & 2.7 & 2.1 & 81.5 & 11.0 & 2.7 \\
\hline defendant was a drug addict $(n=144)$ & 4.2 & 7.6 & 78.5 & 7.6 & 2.1 \\
\hline $\begin{array}{l}\text { defendant had a history of mental illness } \\
(n=146)\end{array}$ & 1.4 & 2.1 & 40.4 & 29.5 & 26.7 \\
\hline defendant had a loving family $(n=144)$ & 0.7 & 0.7 & 79.9 & 15.3 & 3.5 \\
\hline $\begin{array}{l}\text { defendant was a stranger in the } \\
\text { community }(n=143)\end{array}$ & 1.4 & 2.8 & 93.7 & 1.4 & 0.7 \\
\hline poverty $(n=146)$ & 0.0 & 1.4 & 83.6 & 12.3 & 2.7 \\
\hline child ( $n=146)$ & 0.0 & 1.4 & 61.6 & 26.7 & 10.3 \\
\hline was never given any real help $(n=139)$ & 0.7 & 3.6 & 47.5 & 28.1 & 20.1 \\
\hline $\begin{array}{l}\text { defendant did not express any remorse } \\
(\mathrm{n}=138)\end{array}$ & 21.7 & 18.1 & 56.5 & 2.9 & 0.7 \\
\hline $\begin{array}{l}\text { defendant's accomplice received lesser } \\
\text { punishment in exchange for testimony } \\
(n=146)\end{array}$ & 6.2 & 7.5 & 69.2 & 11.0 & 6.2 \\
\hline $\begin{array}{l}\text { juror held lingering doubt over the } \\
\text { defendant's guilt }(n=149)\end{array}$ & 1.3 & 1.3 & 20.1 & 16.8 & 60.4 \\
\hline
\end{tabular}

3. Future dangerousness is highly aggravating. - Looking at Table 4, a majority of jurors would be at least slightly more likely to impose death if the defendant had a history of violent crime, with over a quarter being much more likely. When the question of the defendant's future dangerousness was put more directly-the "defendant might be a danger to society in the future" $-57.9 \%$ reported that they would be more likely to vote for death. ${ }^{90}$ Moreover, $78.7 \%$ believed the defendant actually presented

adjusting for the most important and statistically significant legitimate case characteristics").

90. See infra Table 8. 
such a risk. ${ }^{91}$ These results comport with prior studies that emphasize the pervasive role future dangerousness plays in and on the minds of capital sentencing jurors. ${ }^{92}$

Interestingly, jurors tended to attach little mitigating weight to the absence of any previous criminal history. Less than a quarter thought that a clean record was mitigating. Similarly, only slightly more than a quarter said that they would be either slightly or much less likely to vote for death if they thought the defendant "would be a well-behaved inmate."93 In short, while future dangerousness is highly aggravating, lack of future dangerousness is only moderately mitigating.

One final observation: While race of the defendant generally appears to have little effect on juror reactions to aggravating and mitigating circumstances, ${ }^{\mathrm{S}} 14$ it does appear to influence juror reactions to future dangerousness. Of white jurors, $61.7 \%$ responded that the fact that the "defendant might be a danger to society in the future" would make them more likely to impose a death sentence, while only $36.5 \%$ said it would make them just: as likely. ${ }^{95}$ For black jurors, the picture is reversed, with $62.5 \%$ reporting that the risk of the defendant's future dangerousness would leave them just as likely to impose a death sentence and $37.5 \%$ indicating that it would make them more likely. ${ }^{96}$ This finding warrants further investigation. Future dangerousness appears to be one of the primary determinants of capital-sentencing outcomes, and it also appears to be one of the few ways in which white jurors and black jurors think differently about aggravation and mitigation.

4. Lack of remorse is highly aggravating. - Looking still at Table 4, $39.8 \%$ of the jurors were at least slightly more likely to vote for death if the defendant expressed no remorse for his offense. For $21.7 \%$, the defendant's lack of remorse made them much more likely to vote for

91. This is true despite that fact that only $31.8 \%$ of jurors found that the defendant had a history of violent crime. See infra Table 8 . Of those who found that the defendant might be a future danger, $61.7 \%$ treated it as aggravating to some degree. See infra Table 8.

92. See Eisentierg \& Wells, supra note 7, at 7 ("[O]ver three-quarters of the jurors believe that the evidence in their case established that the defendant would be dangerous in the future."); id. at 4 ("Expectations about future dangerousness play a substantial role in juror deliberations."); see also Bowers \& Steiner, supra note 18, at 58-60 (emphasizing important role of parole eligibility in decisionmaking of capital jurors from several states); cf. Sally Costanzo 8: Mark Costanzo, Life or Death Decisions: An Analysis of Capital Jury Decision Making Under the Special Issues Sentencing Framework, 18 Law \& Hum. Behav. 151,168 (1994) (concluding based on interviews with twenty-seven Oregon jurors from nine capital cases that "in the [special issues] framework, the issue of future dangerousness plays a prominent, if not central, role").

93. See supra 'Table 4.

94. See supra note 58; infra Table 9.

95. See infra Table 9 .

96. See infra Table 9. 
death. 97 Indeed, among the factors listed in Table 4, only the defendant's prior history of violent crime and future dangerousness were more aggravating than lack of remorse. Moreover, over half of the jurors believed the defendant in the case on which they sat was in fact remorseless, a belief which tended to enhance the factor's aggravating effect. ${ }^{98}$ Furthermore, prosecutors in South Carolina who comment on the defendant's lack of remorse in their closing arguments or during the course of the trial run the risk of committing reversible error, since their comments may be construed as an impermissible comment on the defendant's exercise of his right to remain silent. ${ }^{99}$ Thus, assuming the prosecutors in each of the sample cases made no comment on the defendant's lack of remorse, jurors apparently take note of it all on their own.

\section{Mitigation}

Nothing can stand in the way of a capital defendant's ability to present mitigating evidence. Although the state can "structure" how a jury treats mitigating evidence, ${ }^{100}$ it violates the Eighth Amendment when structuring the evidence turns into obstructing the defendant's plea for life.

For the most part, mitigating evidence falls into three broad categories: reduced culpability, general good character, and lack of future dangerousness. ${ }^{101}$ Evidence of lack of future dangerousness speaks for itself and includes whatever might persuade the jury that the defendant will do

97. More detailed studies suggest that jurors' belief in the defendant's remorsefulness tends to make them less likely to vote for death only in cases in which they do not think the crime was "highly vicious." Where jurors do think the crime was highly vicious, their belief in the defendant's remorsefulness tends to make little difference to the sentencing outcome. See Theodore Eisenberg et al., But Was He Sorry? The Role of Remorse in Capital Sentencing, 83 Cornell L. Rev. (forthcoming September 1998) (manuscript at 2, on file with the Columbia Law Review); see also Scott E. Sundby, The Jury and Absolution: Remorse, Trial Tactics and the Death Penalty, 83 Cornell L. Rev. (forthcoming September 1998) (manuscript at 26-40, on file with the Columbia Law Review) (examining dangers in a trial strategy in which the defendant denies any responsibility for the offense); Lawrence $T$. White, Juror Decision Making in the Capital Penalty Trial, 11 Law \& Hum. Behav. 113, 124 tbl.6 (1987) (noting based on study of mock jurors the salience of "[d] efendant showed no remorse" among the "[r] easons [g]iven for [c] hoosing the [d] eath [p]enalty"); Mark Costanzo \& Julie Peterson, Attorney Persuasion in the Capital Penalty Phase: A Content Analysis of Closing Arguments, J. Soc. Issues, Summer 1994, at 125, 137 (concluding based on "content analysis" of prosecution and defense closing arguments in twenty California capital cases that " $[w]$ henever possible, prosecutors emphasized the defendant's apparent lack of remorse").

98. See infra Table 8.

99. See State v. Diddlemeyer, 371 S.E.2d 793, 795 (S.C. 1988); State v. Hawkins, 357 S.E.2d 10, 13 (S.C. 1987); State v. Arther, 350 S.E.2d 187, 191 (S.C. 1986).

100. See Johnson v. Texas, 509 U.S. 350, 362 (1993).

101. See Carol S. Steiker \& Jordan M. Steiker, Let God Sort Them Out? Refining the Individualization Requirement in Capital Sentencing, 102 Yale L.J. 835, 846 (1992) (book review); see also James R. Acker \& Charles S. Lanier, In Fairness and Mercy: Statutory Mitigating Factors in Capital Punishment Laws, 30 Crim. L. Bull. 299, $304-09$ (1994) 
no more harm, such as evidence of good behavior while in prison between arrest arid trial. ${ }^{102}$ Evidence of general good character includes evidence of the defendant's "positive character traits and past good works."103

Evidence of reduced culpability is slightly more complicated. Penalty-phase culpability is not the same as guilt-phase culpability. ${ }^{104} \mathrm{~A}$ defendant's culpability may be great enough to convict, yet not great enough to sentence him to death. Evidence that reduces a defendant's culpability for purposes of the penalty phase can be broken down into two basic categories, which I'll call "proximate" and "remote." Evidence of "proximate" reduced culpability is evidence that "suggests any impairment of a defendant's capacity to control his or her criminal behavior, or to appreciate its wrongfulness or likely consequences." 105 Evidence of "remote" reduced culpability, in contrast, focuses on the defendant's character. It includes such things as abuse as a child and other deprivations that may have helped shape the defendant into the kind of person for whom a capital crime was a conceivable course of action. In short, proximate reduced culpability speaks to the defendant's lack of responsibility for what he has done; remote reduced culpability speaks to his lack of responsibility for who he is.

Most of the factors about which the survey asked involved reduced culpability, either proximate or remote. None of the factors about which the jurors were asked directly related to the defendant's general good character. ${ }^{106}$ Responses to the two factors related to lack of future dangerousness-that the defendant had "no previous criminal record" and that the defendant "would be a well-behaved inmate"-suggest that while this fact has some mitigating potential, its impact is relatively modest, especially in comparison to the number of jurors who treat the existence of future dangerousness as aggravating. ${ }^{107}$ So, for example, only about a quarter of the jurors attributed mitigating effect to the likelihood that the defendant would be well-behaved, and only a fifth did so to the fact that the defendant had no previous criminal record. Moreover, most jurors

(breaking mitigatirg evidence into "offender's responsibility and culpability," "future dangerousness," and "general deserts").

102. See, e.g., Skipper v. South Carolina, 476 U.S. 1, 5 (1986) (" $[E]$ vidence that the defendant would not pose a danger if spared (but incarcerated) must be considered potentially mitigating.").

103. Steiker \& Steiker, supra note 101, at 847.

104. See, e.g., Phyllis L. Crocker, Concepts of Culpability and Deathworthiness: Differentiating Between Guilt and Punishment in Death Penalty Cases, 66 Fordham L. Rev. 21, 26 (1997) ("The punishment-phase determination is not a recapitulation of the guiltphase decision .....”).

105. Steiker \& Steiker, supra note 101, at 846.

106. The one exception here may be evidence that the defendant "had a loving family," and this factor had very little impact, with $79.9 \%$ saying it would leave them just as likely to vote for death. See supra Table 4.

107. See supra Table 4. 
who said these factors were at all mitigating thought they were only slightly mitigating. ${ }^{108}$

1. "Residual doubt" over the defendant's guilt is the most powerful "mitigating" fact. - Table 4 suggests that the best thing a capital defendant can do to improve his chances of receiving a life sentence has nothing to do with mitigating evidence strictly speaking. The best thing he can do, all else being equal, ${ }^{109}$ is to raise doubt about his guilt. Although a disturbingly large minority of jurors reported that they would be just as likely to impose death if they had lingering doubts about the defendant's guilt, $60.4 \%$ said they would be much less likely to impose death, and $77.2 \%$ said they would be at least slightly less likely. ${ }^{110}$ However, among those twenty-eight jurors who said they actually held lingering doubt over the defendant's guilt, only $46.4 \%$ said it made them much less likely to vote for death, and only $57.1 \%$ said it made them at least slightly less likely. ${ }^{111}$ Fully $35.7 \%$ said it made no difference to them. ${ }^{112}$ Learned Hand once wrote that the thought of an innocent man condemned was little more

108. See supra Table 4.

109. Of course, all else is often not equal. Among other things, a capital defendant who completely but unsuccessfully denies his responsibility during the guilt phase may seriously jeopardize his case in mitigation at the penalty phase. See, e.g., Sundby, supra note 97, at 45 ("Without some prior acceptance of responsibility [during the guilt phase], therefore, mitigation evidence bearing on the defendant's upbringing and mental capabilities is likely to be seen through a jaundiced perspective ...."). Although no one knows for certain how many people have been erroneously convicted of capital crimes, one estimate puts the number at around 350. See Hugo Bedau \& Michael Radelet, Miscarriages of Justice in Potentially Capital Cases, 40 Stan. L. Rev. 21, 35-36 tbls.1 \& 2 (1987) (claiming to have identified 350 "potentially capital" cases since 1900, 139 of which resulted in death sentences and 23 in executions); see also Michael Radelet et al., In Spite of Innocence: Erroneous Convictions in Capital Cases 272 (1992) (claiming to have identified an additional sixty-six "potentially capital cases"). But cf. Stephen J. Markman \& Paul G. Cassell, Protecting the Innocent: A Response to the Bedau-Radelet Study, 41 Stan. L. Rev. 121, 121, 159-60 (1988) (arguing that Bedau-Radelet study is "severely flawed in critical respects" and that "[t]he minimal but unavoidable risk of error in the administration of capital punishment must not be allowed to induce a 'failure of nerve' that would paralyze society from taking the steps necessary to protect its citizens").

The extreme nature of capital crimes and the extreme nature of the penalty for capital crimes tend in various ways to increase the risk of erroneous convictions in capital cases. Moreover, whatever additional care and attention capital cases receive from the legal system is not, according to one author, likely to offset these risks. See Samuel $R$. Gross, The Risks of Death: Why Erroneous Convictions Are Common in Capital Cases, 44 Buff. L. Rev. 469, 472-73 (1996).

110. See supra Table 4. The state can nonetheless prevent defense counsel from arguing residual doubt during the penalty phase, because residual doubt is one of the few things the Supreme Court does not include within its otherwise expansive definition of "mitigation." See Franklin v. Lynaugh, 487 U.S. 164, 174 (1988) ("This Court's prior decisions ... . fail to recognize a constitutional right to have ... [residual] doubts considered as a mitigating factor."). Nor is residual doubt "mitigating" under South Carolina law. See State v. Southerland, 447 S.E.2d 862, 868 (S.C. 1994).

111. See infra Table 8.

112. See infra Table 8. 
than a "ghost" that haunted the law. ${ }^{113}$ Capital jurors appear to take the matter more seriously, but perhaps not seriously enough.

2. Proximate culpability-Evidence of mental retardation is highly mitigating, and evidence of the defendant's youthfulness is significantly mitigating. Evidence that the defendant was mentally retarded was almost as powerful as lingering doubt over his guilt. Among the jurors surveyed, 29.5\% reported that the defendant's mental retardation would make them slightly less likely to vote for death, and $44.3 \%$ reported that it would make them much less likely, for a total of 73.8\%.114 However, of the sixteen jurors in the survey who actually believed the defendant was mentally retarded, only seven found it mitigating. ${ }^{115}$ Nine of them said it would leave them just as likely to vote for death. ${ }^{116}$ Like mental retardation, the deferidant's age is also significantly mitigating, with $41.5 \%$ of the jurors reporting that they would give at least some mitigating weight to the fact that the defendant was under eighteen at the time of the crime. ${ }^{117}$

3. Proximate culpability-Circumstances over which the defendant had no control and that diminish his individual responsibility at the time of the offense are highly mitigating. ${ }^{118}$ - Returning for a moment to Table 2, a little more than half of the jurors reported that they would be at least slightly less likely to vote for death if the killing was committed under the influence of extreme mental or emotional disturbance, and almost a quarter of them reported that this fact would make them much less likely to vote for death. ${ }^{119}$ Similarly, a majority of jurors would be at least slightly less

113. See United States v. Garsson, 291 F. 646, 649 (S.D.N.Y. 1923) ("Our dangers do not lie in too little tenderness to the accused. Our procedure has been always haunted by the ghost of the innocent man convicted. It is an unreal dream."); accord United States v. Liss, 137 F.2d 995, 999 (2d Cir. 1943) (Hand, J.) ("phantom"); Di Carlo v. United States, 6 F.2d 364, 368 (2d Cir. 1925) (Hand, J.) ("ghostly phantom").

114. See supra Table 4.

115. See infra Table 8.

116. See infra Table 8.

117. See supra Table 4. The fact that most jurors thought the defendant's youthfulness was rnitigating and not aggravating may be due at least in part to the fact that South Carolina law defines youthfulness as mitigating. See supra note 41. In other states, such as Texas and California, state law does not say whether youthfulness is aggravating or mitigating. Consequently, jurors in these states may think that age, as well as other factors such as mental retardation, are aggravating inasmuch as these factors suggest either the opportunity or the propensity for future violence. See generally Ellen Fels Berkman, Note, Mental Illness as an Aggravating Circumstance in Capital Sentencing, 89 Colum. L. Rev. 291, 299-300 (1989) (noting that prosecutors may try to use mental illness as an aggravating factor and arguing that such a use is inconsistent with existing constitutional doctrine).

118. This finding is consistent with the understanding of mitigation implicit in most state capital sentencing statutes. See Steiker \& Steiker, supra note 101, at 840 " "We discern a firm societal consensus, based on current statutes and common law tradition, that evidence of reduced culpability-and only such evidence-is an indispensable part of capital sentencing.").

119. See supıa Table 2. 
likely to vote for death if the defendant had a history of mental illness. ${ }^{120}$ All of this suggests that evidence of diminished proximate culpability can have relatively strong mitigating appeal.

However, not everything that diminishes an offender's self-control at the time of the offense is mitigating in jurors' minds. Jurors were willing to excuse a defendant if his lack of control at the time of the offense was due to something beyond his control, but they were noticeably less sympathetic if they thought the defendant's lack of control was his own fault. Only $18.5 \%$, for example, would attach mitigating significance to the fact that the killing was committed under the influence of drugs, and only $18.3 \%$ would attach mitigating significance to the fact that the killing was committed under the influence of alcohol. ${ }^{121}$ Nor did being a drug addict or an alcoholic have much mitigating potential. ${ }^{122}$ Indeed, more jurors thought drug addiction was aggravating than mitigating ( $11.8 \%$ compared to $9.7 \%) .^{123}$

4. Remote Culpability-Circumstances over which the defendant had no control and that may have helped form (or misform) his character had a noticeable but limited mitigating effect. - Looking again at Table 4, a third of jurors would assign some mitigating weight to the fact that the defendant had been seriously abused as a child, although nearly two-thirds would assign it no weight. Similarly, only $15.0 \%$ attached any mitigating significance to the fact that the defendant had a background of extreme poverty, ${ }^{124}$ although this figure increased to $31.6 \%$ when the factor was actually present. ${ }^{125}$ On the other hand, nearly half of the jurors assigned some mitigating weight to the fact that the defendant had been in state institutions but had never received any "real help or treatment" for his problems, although almost the same proportion would attach no significance to this fact. ${ }^{126}$

In sum, notions of collective or societal responsibility for shaping the defendant's character played some role in jurors' capital sentencing decision, especially if it appeared that the defendant tried to get help for his problems but society somehow failed him. Notions of individual responsibility, however, played a larger role. ${ }^{127}$ Jurors were not completely un-

120. See supra Table 4. Still, only about a fifth to a quarter of the jurors believed that either of these factors was actually present in the case on which they sat. Only $25.7 \%$ found that the killing was committed under the influence of extreme mental or emotional disturbance, see infra Table 6 , and only $18.1 \%$ found that the defendant had a history of mental illness. See infra Table 8.

121. See supra Table 2.

122. See supra Table 4.

123. See supra Table 4.

124. See supra Table 4.

125. See infra Table 8.

126. See supra Table 4. Again, only about a fifth to a quarter of the jurors found that these circumstances were actually present in the case on which they sat. See infra Table 8.

127. Cf. Eisenberg et al., supra note 49 , at 379 (concluding based on Capital Jury Project study of South Carolina jurors that jurors "seem anxious to emphasize the 
sympathetic to factors that reduced the defendant's responsibility for who he was, but they were more persuaded by factors that reduced his responsibility for what he had done, at least if he had no control over those factors.

5. "Relative culpability" plays little role. - Codefendants often turn on one another, and defendants in capital cases have a particularly strong incentive to cooperate with the state, since cooperation can often be exchanged for a sentence of less than death. Such bargains may be routine, but they are also troubling. Why should otherwise similarly situated defendants receive different treatment based on who gets to the prosecutor's office first? Consequently, if jurors realize that one codefendant escaped death just because he cooperated with the state, they might be less inclined to condemn the other codefendant.

In fact, ferw jurors actually seem to think like that. Although $17.2 \%$ said they would be less likely to vote for death if the defendant's accomplice received lesser punishment in exchange for testimony against the defendant, slightly over two-thirds said they would be just as likely to impose death under such circumstances. ${ }^{128}$ Jurors perhaps take the view that the defendant should not escape the full measure of punishment just because his codefendant did.

Keep in mind that jurors were not actually told to assume that the relative culpability of the two defendants was the same, i.e., that the only difference between them was that one cooperated with the state and the other didn't. Whether this information would have made a difference is impossible to know. Moreover, it's worth noting that support for the death penalty in public opinion polls drops from $70-76 \%$ when respondents are asked whether or not they support the death penalty in the abstract to $25-29 \%$ when they are asked whether they support the death penalty for a defendant who was "[o]nly an accomplice to the killing." 129

\section{CONCLUSION}

My goal here has been modest. I've tried only to describe what jurors who have actually participated in a capital trial think about various aggravating and mitigating circumstances. I choose for the time being to leave it to others and to future work to explore what lessons, if any, this data holds for how, if at all, we should restructure our system of capital sentencing; to reveal the gaps, if any, that exist between how that system actually functions and how our moral and constitutional norms expect it to function; and so on.

defendant's responsibility for his fate, for it was his conduct that ultimately triggered the sequence of events leading up to the sentencing decision"); Sundby, supra note 21, at 1139 ('[E]xperts' explanations of human behavior that run contrary to notions of free will are hard to sell to the jury.").

128. See supra Table 4.

129. Gross, supra note 5 , at 53 tbl.6. 
For now, I return to my original question, what should you say to the jury? All else being equal .... .

The data presented here suggest that defense attorneys should try to get the defendant to show some remorse for what he has done, and do everything possible to convince the jury that he will not do it again. Moreover, they should, if possible, emphasize that the crime was committed under extreme emotional or mental disturbance. But they should also realize that pleas premised on alcohol or drug intoxication will likely have limited effect. Likewise, they should realize that while describing how the defendant was abused as a child or grew up in extreme poverty will help, individual responsibility remains a strong norm in the minds of most capital jurors. 
[Vol. 98:1538

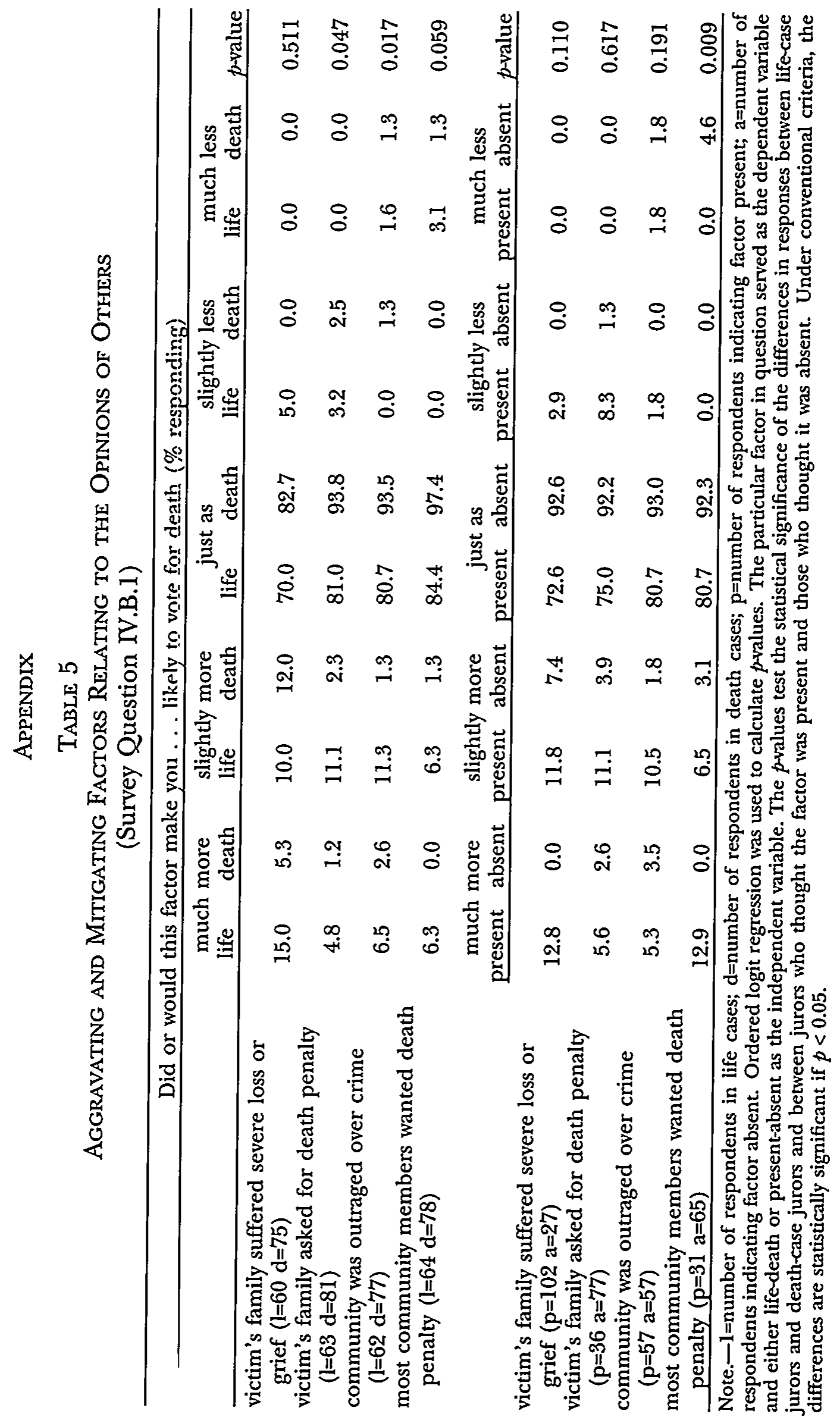




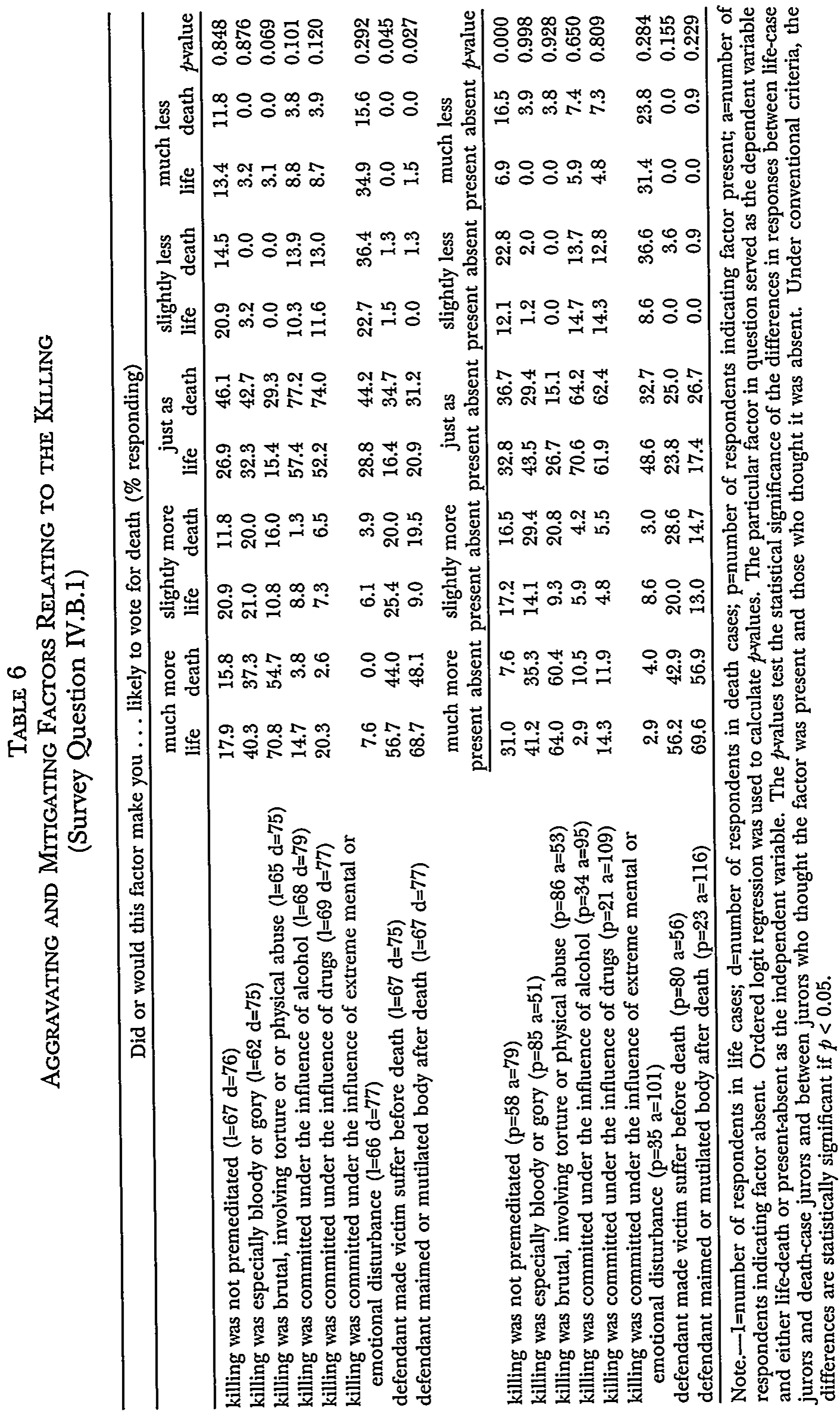




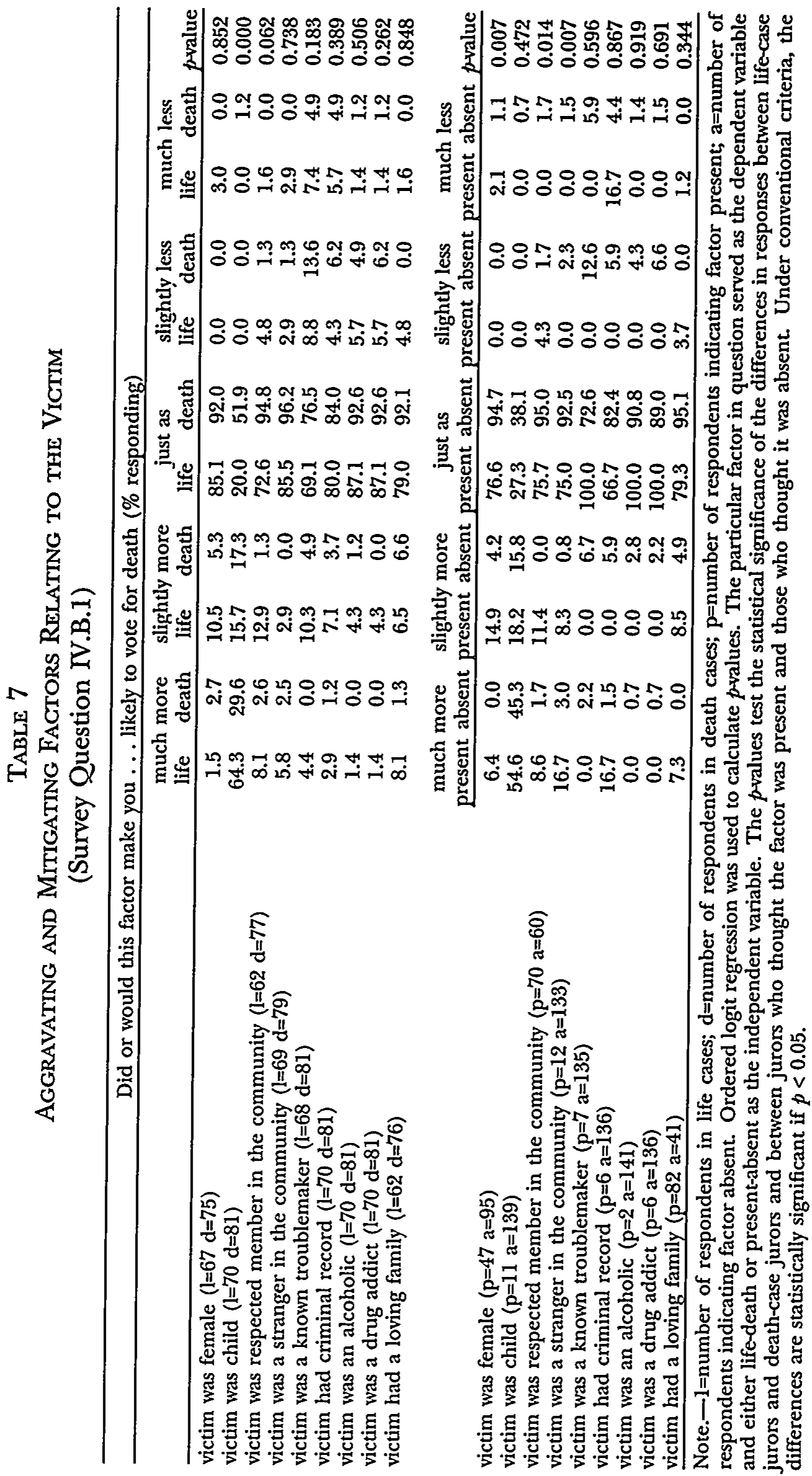




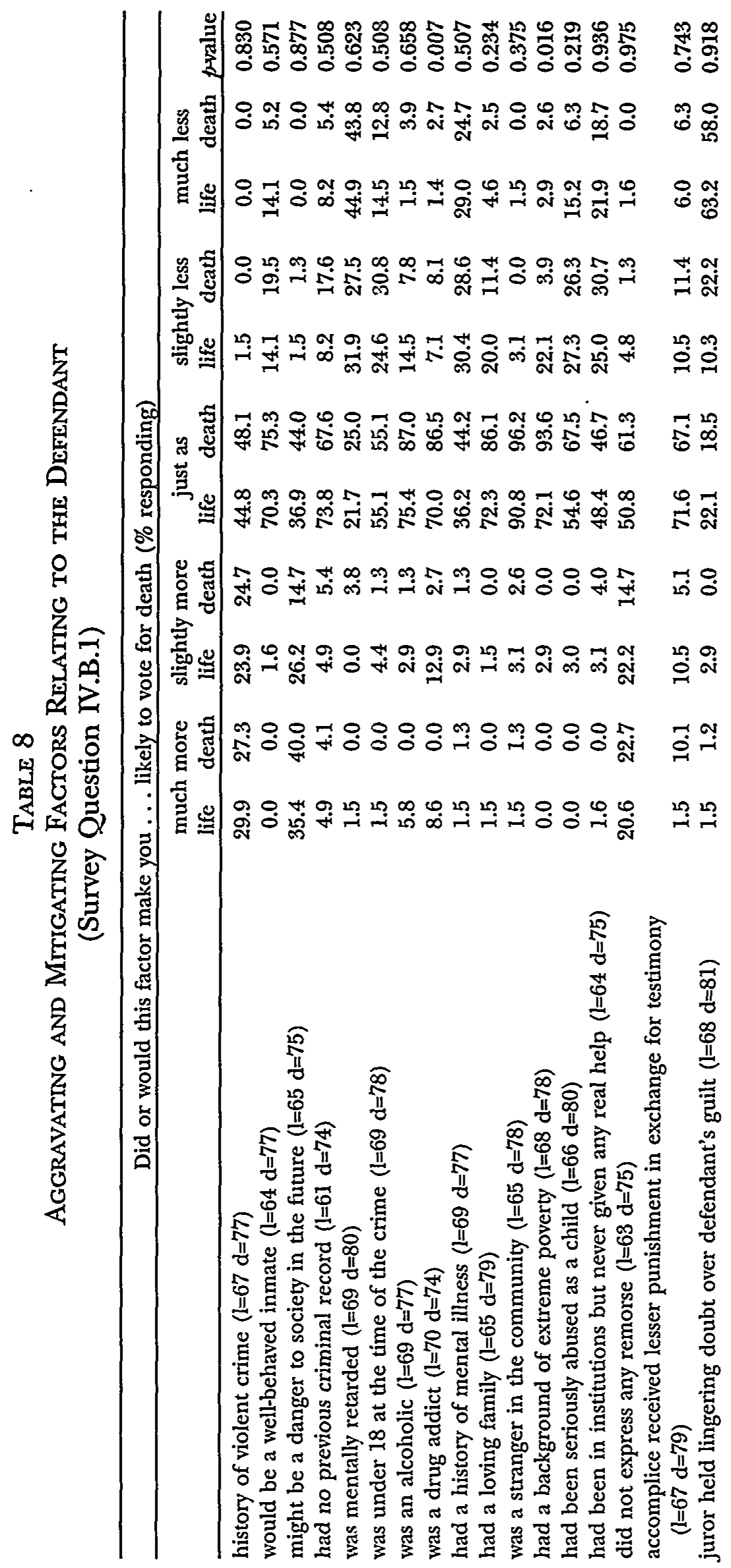




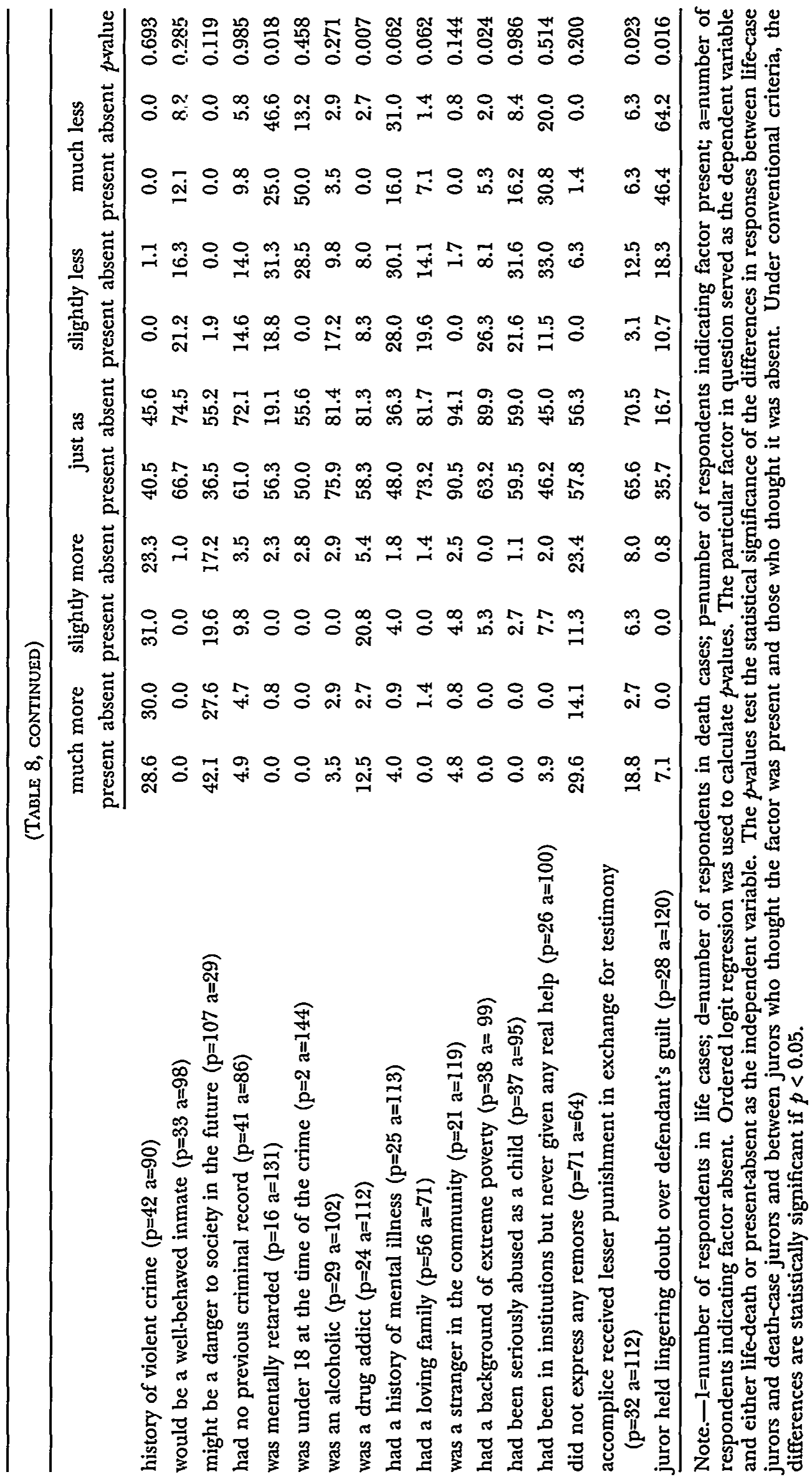


TABle 9

Aggravating and Mitigating Factors

COMPARISON OF BLACK AND WHITE JURORS

(Survey Question IV.B.1)

\begin{tabular}{|c|c|c|c|c|c|c|c|}
\hline \multicolumn{8}{|c|}{ Did or would this factor make you ... likely to vote for death (\% responding) } \\
\hline & \multicolumn{2}{|c|}{ more } & \multicolumn{2}{|c|}{ just as } & \multicolumn{2}{|c|}{ less } & \multirow[b]{2}{*}{$p$-value } \\
\hline & black & white & black & white & black & white & \\
\hline \multicolumn{8}{|c|}{ Factors ReLating to the Opinions of Others } \\
\hline $\begin{array}{l}\text { victim's family suffered severe } \\
\text { loss or grief }(b=23 w=111)\end{array}$ & 17.4 & 21.6 & 78.3 & 76.6 & 4.4 & 1.8 & 0.524 \\
\hline $\begin{array}{l}\text { victim's family asked for death } \\
\text { penalty }(b=25 w=118)\end{array}$ & 4.0 & 10.2 & 88.0 & 88.1 & 8.0 & 1.7 & 0.097 \\
\hline $\begin{array}{l}\text { community was outraged over } \\
\text { crime }(b=22 \quad w=116)\end{array}$ & 9.1 & 10.3 & 77.3 & 89.7 & 13.6 & 0.0 & 0.066 \\
\hline $\begin{array}{l}\text { most community members } \\
\text { wanted death penalty } \\
(b=24 \quad w=117)\end{array}$ & 8.3 & 6.0 & 83.3 & 93.2 & 8.3 & 0.9 & 0.442 \\
\hline \multicolumn{8}{|c|}{ FACTORS RELATING TO THE KILIING } \\
\hline $\begin{array}{l}\text { killing was not premeditated } \\
(b=23 \mathrm{w}=119)\end{array}$ & 43.5 & 31.1 & 26.1 & 38.7 & 30.4 & 30.3 & 0.479 \\
\hline $\begin{array}{l}\text { killing was especially bloody or } \\
\text { gory }(b=21 \quad w=115)\end{array}$ & 62.0 & 59.1 & 38.1 & 37.4 & 0.0 & 3.5 & 0.730 \\
\hline $\begin{array}{l}\text { killing was brutal, involving } \\
\text { torture or physical abuse } \\
\text { (b=22 } w=117)\end{array}$ & 77.3 & 76.1 & 18.2 & 23.1 & 4.6 & 0.9 & 0.975 \\
\hline $\begin{array}{l}\text { killing was committed under } \\
\text { influence of alcohol } \\
(b=24 w=122)\end{array}$ & 29.2 & 10.7 & 41.7 & 73.0 & 29.2 & 16.4 & 0.681 \\
\hline $\begin{array}{l}\text { killing was committed under } \\
\text { influence of drugs } \\
(b=25 w=120)\end{array}$ & 32.0 & 15.0 & 48.0 & 66.7 & 20.0 & 18.3 & 0.232 \\
\hline $\begin{array}{l}\text { killing was committed under } \\
\text { influence of extreme mental } \\
\text { or emotional disturbance } \\
(b=24 \mathrm{w}=118)\end{array}$ & 12.5 & 7.6 & 33.3 & 37.3 & 54.2 & 55.1 & 0.788 \\
\hline $\begin{array}{l}\text { defendant made victim suffer } \\
\text { before death }(b=23 \quad w=118)\end{array}$ & 78.3 & 72.0 & 21.7 & 26.3 & 0.0 & 1.7 & 0.519 \\
\hline $\begin{array}{l}\text { defendant maimed or mutilated } \\
\text { victim after death } \\
(b=26 \quad w=117)\end{array}$ & 76.9 & 71.8 & 23.1 & 26.5 & 0.0 & 1.7 & 0.571 \\
\hline \multicolumn{8}{|c|}{ FAcTORS RELATING TO THE VICTIM } \\
\hline victim was female $(b=24 w=117)$ & 16.7 & 8.6 & 75.0 & 91.5 & 8.3 & 0.0 & 0.942 \\
\hline victim was child $(b=26 w=124)$ & 69.2 & 60.5 & 26.9 & 39.5 & 3.9 & 0.0 & 0.486 \\
\hline $\begin{array}{l}\text { victim was respected member in } \\
\text { community }(b=22 \quad w=116)\end{array}$ & 31.8 & 7.8 & 59.1 & 89.7 & 9.1 & 2.6 & 0.033 \\
\hline $\begin{array}{l}\text { victim was stranger in } \\
\text { community }(b=25 \quad w=122)\end{array}$ & 16.0 & 3.3 & 76.0 & 94.3 & 8.0 & 2.5 & 0.244 \\
\hline $\begin{array}{l}\text { victim was known troublemaker } \\
\qquad(b=25 w=123)\end{array}$ & 12.0 & 9.0 & 64.0 & 74.8 & 24.0 & 16.3 & 0.643 \\
\hline
\end{tabular}




\begin{tabular}{|c|c|c|c|c|c|c|c|}
\hline \multicolumn{8}{|c|}{ (TABLE 9, CONTINUED) } \\
\hline $\begin{array}{l}\text { victim had criminal record } \\
\qquad(b=26 w=124)\end{array}$ & 7.7 & 7.3 & 73.1 & 83.9 & 19.2 & 8.9 & 0.260 \\
\hline $\begin{array}{l}\text { victim was an alcoholic } \\
(b=26 w=124)\end{array}$ & 7.7 & 2.4 & 84.6 & 91.1 & 7.7 & 6.5 & 0.560 \\
\hline $\begin{array}{l}\text { victim was a drug addict } \\
(\mathrm{b}=26 \mathrm{w}=124)\end{array}$ & 3.9 & 2.4 & 84.6 & 91.1 & 11.5 & 6.5 & 0.572 \\
\hline $\begin{array}{l}\text { victim had a loving family } \\
(b=22 w=115)\end{array}$ & 4.6 & 12.2 & 90.9 & 85.2 & 4.6 & 2.6 & 0.257 \\
\hline \multicolumn{8}{|c|}{ Factors ReLATING to the DefendaNT } \\
\hline $\begin{array}{l}\text { defendant had a history of } \\
\text { violent crime }(b=23 \text { w=120) } \\
\text { defendant would be: a well- }\end{array}$ & 39.1 & 55.0 & 56.5 & 45.0 & 4.4 & 0.0 & 0.118 \\
\hline $\begin{array}{l}\text { behaved inmate }(b=23 w=117) \\
\text { defendant might } b e \text { a danger to }\end{array}$ & 0.0 & 0.9 & 69.6 & 73.5 & 30.4 & 25.6 & 0.597 \\
\hline $\begin{array}{l}\text { society in the future } \\
(b=24 \mathrm{w}=115) \\
\text { defendant had no vrevious }\end{array}$ & 37.5 & 61.7 & 62.5 & 36.5 & 0.0 & 1.7 & 0.043 \\
\hline $\begin{array}{l}\text { criminal record }(b=23 w=111) \\
\text { defendant was mencally retarded }\end{array}$ & 8.7 & 9.9 & 69.6 & 71.2 & 21.7 & 18.9 & 0.738 \\
\hline $\begin{array}{l}(b=26 w=122) \\
\text { defendant was under } 18 \text { at the }\end{array}$ & 0.0 & 3.3 & 30.8 & 22.1 & 69.2 & 74.6 & 0.653 \\
\hline $\begin{array}{l}\text { time of the crime } \\
(b=25 w=121) \\
\text { defendant was an alcoholic }\end{array}$ & 4.0 & 3.3 & 64.0 & 53.7 & 32.0 & 43.0 & 0.322 \\
\hline $\begin{array}{l}(b=25 w=120) \\
\text { defendant was a drug addict }\end{array}$ & 8.0 & 4.2 & 72.0 & 83.3 & 20.0 & 12.5 & 0.650 \\
\hline $\begin{array}{l}(b=25 w=118) \\
\text { defendant had a history of }\end{array}$ & 12.0 & 11.9 & 72.0 & 79.7 & 16.0 & 8.5 & 0.469 \\
\hline $\begin{array}{l}\text { mental illness }(b=25 \mathrm{w}=120) \\
\text { defendant had a loving family }\end{array}$ & 8.0 & 2.5 & 44.0 & 40.0 & 48.0 & 57.5 & 0.289 \\
\hline $\begin{array}{l}(b=24 w=119) \\
\text { defendant was a stranger in the }\end{array}$ & 0.0 & 1.7 & 87.5 & 79.0 & 12.5 & 19.3 & 0.551 \\
\hline & 4.6 & 4.2 & 86.4 & 95.0 & 9.1 & 0.8 & 0.167 \\
\hline $\begin{array}{l}\text { extreme poverty ( } b=23 w=122) \\
\text { defendant had been seriously } \\
\text { abused as a child }\end{array}$ & 4.4 & 0.8 & 69.6 & 86.1 & 26.1 & 13.1 & 0.243 \\
\hline $\begin{array}{l}(b=24 w=121) \\
\text { defendant had been in }\end{array}$ & 0.0 & 1.7 & 70.8 & 60.3 & 29.2 & 38.0 & 0.485 \\
\hline $\begin{array}{l}\text { institutions but never given } \\
\text { any real help ( } b=2,1 \mathrm{w}=117 \text { ) } \\
\text { defendant did not express any }\end{array}$ & 0.0 & 5.1 & 52.4 & 47.0 & 47.6 & 47.9 & 0.843 \\
\hline $\begin{array}{l}\text { remorse ( } b=24 \mathrm{w}=113) \\
\text { defendant's accomplice received } \\
\text { lesser punishment in } \\
\text { exchange for testimony } \\
(\mathrm{b}=24 \text { w }=191 \text { ) }\end{array}$ & 33.3 & 41.6 & 62.5 & 54.9 & 4.2 & 3.5 & 0.462 \\
\hline $\begin{array}{l}\text { juror held lingering doubt over } \\
\text { defendant's guilt } \\
(b=25 w=123)\end{array}$ & & & & & 12.5 & 18.2 & 0.734 \\
\hline & 0.0 & 3.3 & 32.0 & 17.9 & 68.0 & 78.9 & 0.300 \\
\hline
\end{tabular}

Note. $-b=$ number of black respondents; $w=$ number of white respondents. Ordered logit regression was used to calculate pralues. The pralues test the statistical significance of the differences in responses between black jurors and white jurors. Under conventional criteria, the differences are statistically significant if $p<0.05$. 
TABLE 10

Aggravating and Mrtigating Factors

Comparison of Multistate Jurors and South Carolina Jurors

(Survey Question IV.B.1)

Did or would this factor make you ... likely to vote for death (\% responding)

$\begin{array}{cc}\begin{array}{c}\text { Multistate Jurors } \\ \text { (n=1017) }\end{array} & \begin{array}{c}\text { South Carolina Jurors } \\ \text { (n ranges from }\end{array} \\ \text { more } & \text { less to 151) } \\ \end{array}$

pralue

Factors Relating to THE Opinions of Others

victim's family suffered severe

loss or grief

victim's family asked for death penalty

community was outraged over crime

most community members

wanted death penalty

15

12

11

8

Factors Relating to the KILLING

killing was not premeditated

killing was especially bloody or gory

killing was brutal, involving torture or physical abuse

killing was committed under influence of alcohol

killing was committed under influence of drugs

killing was committed under influence of extreme mental or emotional disturbance

defendant made victim suffer before death

defendant maimed or mutilated victim after death
27

63

82

15

16

6

80

77
4

2

3

4

35

6

2

28

26

64

2

3

Factors Relating to THE Victim

victim was female

victim was child

victim was respected member in community

victim was stranger in community

victim was known

troublemaker

victim had criminal record

victim was an alcoholic

victim was a drug addict

victim had a loving family

defendant had a history of violent crime

defendant would be a wellbehaved inmate

defendant might be a danger

to society in the future

defendant had no previous

criminal record

Factors Relating to the Defendant

$\begin{array}{rrrrr}10 & 2 & 10 & 1 & 1.000 \\ 71 & 1 & 62 & 1 & 1.000 \\ 9 & 3 & 12 & 4 & 1.000 \\ & & & & \\ 2 & 4 & 6 & 3 & 0.315 \\ 9 & 24 & 9 & 17 & 0.259 \\ 9 & 21 & 7 & 11 & 0.545 \\ 3 & 10 & 3 & 7 & 1.000 \\ 5 & 13 & 3 & 7 & 1.000 \\ 10 & 4 & 11 & 3 & 1.000\end{array}$

$\begin{array}{rrrrr}65 & 4 & 53 & 1 & 0.384 \\ 2 & 28 & 1 & 26 & 1.000 \\ 50 & 4 & 58 & 1 & 0.191 \\ 9 & 35 & 10 & 20 & 0.280\end{array}$


(TABLE 10, CONTINUED)

\begin{tabular}{|c|c|c|c|c|c|}
\hline $\begin{array}{l}\text { defendant was mentally } \\
\text { retarded }\end{array}$ & 2 & 81 & 3 & 74 & 0.672 \\
\hline defendant was under 18 at & & & & & \\
\hline $\begin{array}{l}\text { the time of the crime } \\
\text { defendant was an alcoholic }\end{array}$ & 2 & $\begin{array}{l}46 \\
13\end{array}$ & $\begin{array}{l}3 \\
5\end{array}$ & $\begin{array}{l}42 \\
14\end{array}$ & $\begin{array}{l}0.671 \\
1.000\end{array}$ \\
\hline $\begin{array}{l}\text { defendant was an alcoholic } \\
\text { defendant was a drug addict }\end{array}$ & $\begin{array}{l}4 \\
8\end{array}$ & $\begin{array}{l}13 \\
12\end{array}$ & $\begin{array}{r}5 \\
12\end{array}$ & $\begin{array}{l}14 \\
10\end{array}$ & 0.374 \\
\hline $\begin{array}{l}\text { defendant had a history of } \\
\text { mental illness }\end{array}$ & 3 & 67 & 4 & 56 & 0.703 \\
\hline defendant had a loving family & 4 & 14 & 1 & 19 & 0.170 \\
\hline $\begin{array}{l}\text { the community } \\
\text { defendant had a background }\end{array}$ & 3 & 4 & 4 & 2 & 0.592 \\
\hline $\begin{array}{l}\text { of extreme poverty } \\
\text { defendant had been seriously }\end{array}$ & 1 & 15 & 1 & 15 & 1.000 \\
\hline $\begin{array}{l}\text { abused as a child } \\
\text { defendant had been in }\end{array}$ & 1 & 43 & 1 & 37 & 1.000 \\
\hline $\begin{array}{l}\text { institutions but never given } \\
\text { any real help } \\
\text { defendant did not express any }\end{array}$ & 3 & 52 & 4 & 48 & 0.711 \\
\hline $\begin{array}{l}\text { remorse } \\
\text { defendant's accomplice }\end{array}$ & 38 & 9 & 40 & 4 & 0.234 \\
\hline $\begin{array}{l}\text { received lesser punishment } \\
\text { in exchange for testimony } \\
\text { juror held lingering; doubt }\end{array}$ & 8 & 23 & 14 & 17 & 0.184 \\
\hline over defendant's guilt & 3 & 81 & 3 & 77 & 1.000 \\
\hline
\end{tabular}

Note.-Responses of multistate jurors taken from Ellen Blau \& Marla Sandys, The Decision Makers: What Moves Jurors? (March 24, 1998) (unpublished manuscript, on file with the Columbia Law Review) (multistate jurors include jurors from Alabama, California, Florida, Georgia, Indiana, Kentucky, Louisiana, Missouri, North Carolina, Pennsylvania, Texas, and Virginia). Fisher's exact was used to calculate $p$-values. The p-values test the statistical significance of the differences in responses between multistate jurors and South Carolina jurors. Under conventional criteria, the differences are statistically significant if $p<0.05$. 